\title{
Electrochemical interaction of Shewanella oneidensis MR-1 and its outer membrane cytochromes OmcA and MtrC with hematite electrodes
}

\author{
Leisa A. Meitl ${ }^{\mathrm{a}}$, Carrick M. Eggleston ${ }^{\mathrm{a}, *}$, Patricia J.S. Colberg ${ }^{\mathrm{b}}$, Nidhi Khare ${ }^{\mathrm{a}}$, \\ Catherine L. Reardon ${ }^{c}$, Liang Shi ${ }^{\mathrm{c}}$ \\ ${ }^{a}$ Department of Geology and Geophysics, University of Wyoming, Laramie, WY 82071, USA \\ ${ }^{\mathrm{b}}$ Department of Civil and Architectural Engineering, University of Wyoming, Laramie, WY 82071, USA \\ ${ }^{\mathrm{c}}$ Microbiology Group, Pacific Northwest National Laboratory, P.O. Box 999, MSIN: P7-50, Richland, WA 99354, USA
}

Received 27 December 2008; accepted in revised form 15 June 2009; available online 28 June 2009

\begin{abstract}
Bacterial metal reduction is an important biogeochemical process in anaerobic environments. An understanding of electron transfer pathways from dissimilatory metal-reducing bacteria (DMRB) to solid phase metal (hydr)oxides is important for understanding metal redox cycling in soils and sediments, for utilizing DMRB in bioremedation, and for developing technologies such as microbial fuel cells. Here we hypothesize that the outer membrane cytochromes OmcA and MtrC from Shewanella oneidensis MR-1 are the only terminal reductases capable of direct electron transfer to a hematite working electrode. Cyclic voltammetry $(\mathrm{CV})$ was used to study electron transfer between hematite electrodes and protein films, $S$. oneidensis MR-1 wild-type cell suspensions, and cytochrome deletion mutants. After controlling for hematite electrode dissolution at negative potential, the midpoint potentials of adsorbed OmcA and MtrC were measured $(-201 \mathrm{mV}$ and $-163 \mathrm{mV}$ vs. $\mathrm{Ag} /$ $\mathrm{AgCl}$, respectively). Cell suspensions of wild-type MR-1, deletion mutants deficient in OmcA $(\Delta o m c A), \operatorname{MtrC}(\Delta m t r C)$, and both OmcA and $\mathrm{MtrC}(\Delta m \operatorname{tr} C-\Delta o m c A)$ were also studied; voltammograms for $\Delta m \operatorname{tr} C-\Delta o m c A$ were indistinguishable from the control. When the control was subtracted from the single deletion mutant voltammograms, redox peaks were consistent with the present cytochrome (i.e., $\Delta o m c A$ consistent with $\mathrm{MtrC}$ and $\Delta m \operatorname{tr} C$ consistent with OmcA). The results indicate that OmcA and MtrC are capable of direct electron exchange with hematite electrodes, consistent with a role as terminal reductases in the $S$. oneidensis MR-1 anaerobic respiratory pathway involving ferric minerals. There was no evidence for other terminal reductases operating under the conditions investigated. A Marcus-based approach to electron transfer kinetics indicated that the rate constant for electron transfer $k_{\text {et }}$ varies from $0.025 \mathrm{~s}^{-1}$ in the absence of a barrier to $63.5 \mathrm{~s}^{-1}$ with a $0.2 \mathrm{eV}$ barrier. (C) 2009 Elsevier Ltd. All rights reserved.
\end{abstract}

\section{INTRODUCTION}

Bacterial metal reduction is a key biogeochemical process in anaerobic environments. The most common natural redox-active metals, $\mathrm{Fe}$ and $\mathrm{Mn}$, are insoluble at mid-range $\mathrm{pH}$, necessitating either a microbe-to-mineral respiratory electron transfer pathway or $\mathrm{Fe}(\mathrm{III})$ solubilization and

\footnotetext{
* Corresponding author. Fax +1 3077666679.

E-mail address: carrick@uwyo.edu (C.M. Eggleston).
}

reduction. Dissimilatory metal-reducing bacteria (DMRB) have been the focus of much recent work because of their abundance in a wide range of natural environments and their involvement in global redox cycling (Myers and Nealson, 1988; Lovley, 1991, 1993, 1997; Lovley et al., 1991; Venkateswaran et al., 1999). DMRB can use a wide variety of compounds as terminal electron acceptors, including organic compounds and redox sensitive metals and radionuclides such as oxidized forms of $\mathrm{U}, \mathrm{Tc}, \mathrm{Np}, \mathrm{Pu}, \mathrm{V}, \mathrm{Mo}, \mathrm{Cr}$, and Se (e.g., Lloyd, 2003; Carpentier et al., 2005; Fredrickson et al., 2008). The metabolic capacity to reduce metals 
and radionuclides has fueled interest in DMRB for bioremediation (Lovley et al., 1989; Lovley, 1995; Fredrickson and Gorby, 1996; Rooney-Varga et al., 1999; Markwiese and Colberg, 2000; Tiedje, 2002; Viamajala et al., 2002). Here, we use voltammetry to study both the energetics and kinetics of electron transfer between hematite electrodes and DMRB as well as key enzymes isolated from DMRB.

Several mechanisms have been proposed for DMRB electron transfer to respiratory oxidants (e.g., Luu and Ramsay, 2003; Hernandez et al., 2004; Gorby et al., 2006; Shi et al., 2007; Marsili et al., 2008; von Canstein et al., 2008). Different species may use different mechanisms, and each may utilize several parallel mechanisms depending on conditions. DMRB utilize an electron transport system that extends from the periplasm to the surface of the cell's outer membrane (Richardson, 2000; Luu and Ramsay, 2003; Hartshorne et al., 2007; Ross et al., 2007; Shi et al., 2007) in order to reduce solid oxidants outside the cell. Cytochromes (and other proteins) that are expressed on the outer cell surface have been hypothesized to be terminal reductases (Beliaev and Saffarini, 1998; Myers and Myers, 2003; Ruebush et al., 2006; Shi et al., 2006, 2008).

Some DMRB reportedly require physical contact with minerals in order to transfer electrons (e.g., Arnold et al., 1988; Lovley and Phillips, 1988; Lovley et al., 1991; Urrutia et al., 1999; Das and Caccavo, 2000; Nevin and Lovley, 2000). Other DMRB appear able to reduce minerals at a distance through use of secreted or naturally-occurring soluble electron shuttles (Hernandez and Newman, 2001; Nevin and Lovley, 2002; Luu and Ramsay, 2003). Several molecular electron shuttles have been proposed, some of which are produced by the cell and others that occur in the environment (e.g., Lovley et al., 1996; Newman and Kolter, 2000; Turick et al., 2002; Marsili et al., 2008; von Canstein et al., 2008). The discovery of electrically-conductive pili or "nanowires" produced by DMRB suggests a solution to the reduction-at-a-distance paradox (Reguera et al., 2005; Gorby et al., 2006), though nanowires are also used in biofilm formation (Reguera et al., 2007). Nanowires may contain proteins such as cytochromes (Gorby et al., 2006), in which case the $c$-type cytochromes may still act as terminal reductases.

Recent research has focused on proteins and other molecules involved in electron transfer to solid terminal electron acceptors (Kim et al., 1999a,b; Newman and Kolter, 2000; Magnuson et al., 2001; Kappler et al., 2004; Lies et al., 2005; Khare et al., 2006b; Taillefert et al., 2007; Marsili et al., 2008; von Canstein et al., 2008). Several DMRB have been sequenced and much is thus known about their redox proteins (e.g., Heidelberg et al., 2002; Methe et al., 2003; Beliaev et al., 2005; Kolker et al., 2005). Here we focus on Shewanella oneidensis MR-1 (abbreviated MR-1), a gram-negative, facultative anaerobe, whose genome encodes for $42 c$-type cytochromes (Heidelberg et al., 2002; Meyer et al., 2004), three of which have been shown to be involved in metal reduction $(\mathrm{OmcA}, \mathrm{MtrC} / \mathrm{OmcB}$ which we refer to as MtrC, and MtrA; Beliaev et al., 2001; Myers and Myers, 2001; Bretschger et al., 2007; Lower et al., 2009). Although MtrD and MtrF are paralogs of MtrA and $\mathrm{MtrC}$, respectively, their role in metal reduction has not yet been shown (Myers and Myers, 2002; Bretschger et al., 2007; Marshall et al., 2006). Cytochromes are localized in various positions spanning the inner and outer membrane of MR-1 and other Shewanella spp., creating a "molecular wire" that may allow the bacteria to access insoluble electron acceptors and move electrons out of the cell (Myers and Myers, 1992, 1997; Richardson, 2000; Beliaev et al., 2001; Croal et al., 2004; DiChristina et al., 2005). OmcA is an 83-kDa deca-heme cytochrome with 708 amino acids and MtrC is $77-\mathrm{kDa}$ deca-heme cytochrome with 671 amino acids (Myers and Myers, 2003). OmcA and MtrC have been localized to the outer surface of the outer membrane (Myers and Myers, 2003; Lower et al., 2009; Shi et al., 2008) or the extracellular matrix (Marshall et al., 2006) in which proteinase $\mathrm{K}$ (digestive enzyme) experiments suggest that OmcA is more prominently exposed on the outer membrane than MtrC (Myers and Myers, 2003). Both cytochromes are hypothesized to be terminal reductases that catalyze electron transfer from the cell to $\mathrm{Fe}(\mathrm{III})$ and $\mathrm{Mn}(\mathrm{IV})$ minerals. These proteins have been shown to form a functional 2:1 complex (Shi et al., 2006) although cells retain some capacity for $\mathrm{Fe}(\mathrm{III})$ reduction in the absence of one or the other cytochrome (Bretschger et al., 2007). MtrC has also been purified as a stable complex with the periplasmic cytochrome MtrA and predicted outer membrane $\beta$ barrel protein MtrB with 1:1:1 stoichiometry and the in vitro ability to reduce soluble and solid iron and manganese (Ross et al., 2007).

Cytochromes are not the only outer membrane proteins in MR-1 involved in $\mathrm{Fe}(\mathrm{III})$ or $\mathrm{Mn}(\mathrm{IV})$ reduction. MtrB is essential to $\mathrm{Fe}(\mathrm{III})$ reduction (Beliaev and Saffarini, 1998; Beliaev et al., 2001) and to proper localization of OmcA and MtrC on the outer membrane (Myers and Myers, 2002). A variety of other molecules are associated with the outer membrane of DMRB, including iron-sulfur proteins and quinones (Richardson, 2000). Among these is prismane, an iron-sulfur protein whose abundance increased in MR-1 in the presence of Fe(III) (Giometti, 2006).

A series of recent studies have focused on the interaction of OmcA and $\mathrm{MtrC}$ with iron or $\mathrm{Mn}(\mathrm{IV})$ oxides. In vitro reductase assays indicate that both OmcA and MtrC can transfer electrons directly to solid substrates, including hematite (Shi et al., 2006; Xiong et al., 2006; Eggleston et al., 2008; Hartshorne et al., 2007). Also, membrane fractions containing these proteins reduce soluble, chelated $\mathrm{Fe}(\mathrm{III})$ and solid-phase $\mathrm{Fe}(\mathrm{III})$ in the presence of an electron donor such as lactate (Myers and Myers, 1993; Ruebush et al., 2006). Protein- and cell-functionalized atomic force microscopy (AFM) tips have been used to show that oxidized forms of both OmcA and MtrC have an affinity for hematite surfaces and that OmcA binds half as frequently but twice as strongly to hematite than does MtrC (Lower et al., 2007). Collectively, these studies suggest that MtrC and OmcA are key outer membrane cytochromes governing electron transfer to solid ferric substrates and electrodes.

Other researchers have investigated the electrochemical activity of Shewanella spp. using graphite or glassy carbon electrodes. Bretschger et al. (2007) demonstrated that 
MtrC, OmcA, CymA, MtrA, MtrB and Type II secretion proteins are all important in energy generation. Kim et al. (1999a,b) investigated anaerobically and aerobically grown Shewanella putrefaciens IR-1 (abbr. IR-1) and found that only anaerobically grown cells showed electrochemical activity. The electrochemical behavior of MR-1 is similar to that of IR-1 (Kim et al., 2002). Cho and Ellington (2007) investigated anaerobically and aerobically grown MR-1 and also only found electrochemical activity in anaerobically grown cells. Recently, voltammograms of Shewanella spp. MR-4 and MR-1 revealed a redox couple that was attributed to flavins adsorbed to the electrode (Marsili et al., 2008). These authors contend that flavins are key mediators in the metal reduction process, and that they may also act as chelators for metal ions. The reason for the differences between the voltammograms of other authors and those of Marsili et al. (2008) are unclear.

Among the studies cited above, there is little information on the energetics and kinetics of electron transfer between iron oxides and either proteins or organisms. Some studies show that electron transfer to iron oxides from proteins or organisms takes place, but do not provide potentials relevant to the energetics of the process. Others use voltammetry (and thus provide potentials), but do not use iron oxide electrodes. Some studies use voltammetry with whole cells, but cannot relate the results to specific proteins or protein complexes. Here, we use cyclic voltammetry (conventional voltammetry with whole-cell suspensions, and protein film voltammetry with proteins) and n-type single-crystal hematite electrodes (chosen as a proxy for natural ferric minerals) to examine electron transfer to and from protein films as well as cell suspensions. This approach allows us to extract both energetic (potential) as well as kinetic information relevant to protein-hematite and organism-hematite interfaces that are somewhat more realistic than in studies using non-oxide electrodes, and to compare the behavior of whole cell suspensions to that of isolated proteins. We hypothesize that OmcA and MtrC are the main terminal reductases able to exchange electrons with a hematite electrode, and that there are differences between electron transfer results for individual proteins as compared to those for whole cells that may reflect the action of functional protein complexes at cell surfaces.

\section{MATERIALS AND METHODS}

\subsection{Hematite electrodes}

The hematite crystals used as electrodes in this work are n-type semiconductors. There is a potential (the "flatband potential", $\left.E_{\mathrm{FB}}\right)$ at which a semiconductor in contact with an electrolyte solution can be poised for which there is no potential difference between the bulk and the surface (Fig. 1, center; Morrison, 1980; Finklea, 1988; Grätzel, 1989). $E_{\mathrm{FB}}$ changes with $\mathrm{pH}$, along with surface charge and potential. At $\mathrm{pH} \mathrm{7,} E_{\mathrm{FB}}$ for our natural hematite crystals is $-300 \mathrm{mV} \pm 150 \mathrm{mV}$ vs. $\mathrm{Ag} / \mathrm{AgCl}$ (data not shown) as determined using the method of Boschloo and Fitzmaurice (1999). This value agrees well with other reported $E_{\mathrm{FB}}$ values (e.g., Anderman and Kennedy, 1988). Our crystals have

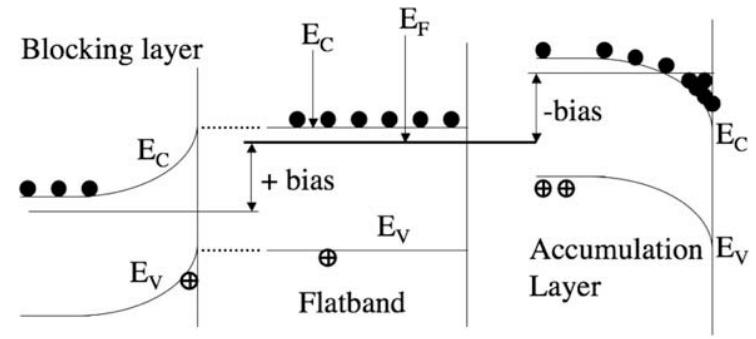

Fig. 1. A cartoon of the main possibilities when biasing an n-type semiconducting electrode such as hematite. Filled circles represent electrons in the conduction band; circles with crosses represent positively charged "holes" (electron vacancies) in the valence band. The vertical lines represent an interface, and the upward direction also represents higher energy. The line labeled $E_{\mathrm{c}}$ represents the conduction band edge, and that labeled $E_{\mathrm{v}}$ represents the valence band edge. Energies between $E_{\mathrm{c}}$ and $E_{\mathrm{v}}$ are within the bandgap and, nominally, have no electronic states (whether occupied or unoccupied), although impurities can contribute a few states in the bulk or at the surface within the bandgap. $E_{\mathrm{F}}$ is the Fermi level, representing the effective chemical potential for electrons in the semiconductor. The middle panel shows the configuration at flatband potential, the left-hand panel represents positive bias (with band bending that creates a depletion layer near the interface), and the right-hand panel represents negative bias (with band being that creates an accumulation layer near the interface). An accumulation layer on hematite increases the probability that an Fe site at the surface will be an $\mathrm{Fe}$ (II) site and thus dissolve. Therefore, an applied electrode potential $E$ that is less than $E_{\mathrm{FB}}$ will lead to reductive dissolution of hematite.

a charge carrier density of about $8 \times 10^{17} \mathrm{~cm}^{-3}$ (Eggleston et al., 2003). If a potential $E<E_{\mathrm{FB}}$ is applied, negative band bending occurs and electrons in the bulk solid will tend to migrate to the surface to form an accumulation layer (Fig. 1, right). The electron concentration at the surface increases, and electron acceptors either adsorbed to the surface or in solution near the electrode surface can be reduced, leading to cathodic current. For hematite, an accumulation layer can also lead to reductive dissolution of the electrode and thus to the introduction of redox-active $\mathrm{Fe}$ into the solution. If $E>E_{\mathrm{FB}}$, positive band bending occurs and surface electrons tend to move into the bulk solid, resulting in a depletion layer and positive charge near the surface of the solid (Fig. 1, left) such that dissolved or adsorbed electron donors can be oxidized. In this case, a barrier exists at the interface such that electron transfer into the bulk solid is impeded, resulting in rectification: relatively high cathodic currents at $E<E_{\mathrm{FB}}$, and small anodic currents at $E>E_{\mathrm{FB}}$ (Fig. 2a).

\subsection{Bacteria and proteins}

The bacteria and proteins used in this study are listed in Table 1. S. oneidensis MR-1 was obtained from the American Type Culture Collection (ATCC No. 700550). Construction of the targeted single gene deletion mutants, $\Delta m t r C$ and $\Delta o m c A$, and the double deletion mutant $\Delta m t r C-\Delta o m c A$ are described elsewhere (Marshall et al., 2006; Bretschger et al., 2007). MtrC (SO1778) and OmcA (SO1779) were purified according to protocol (Shi et al., 

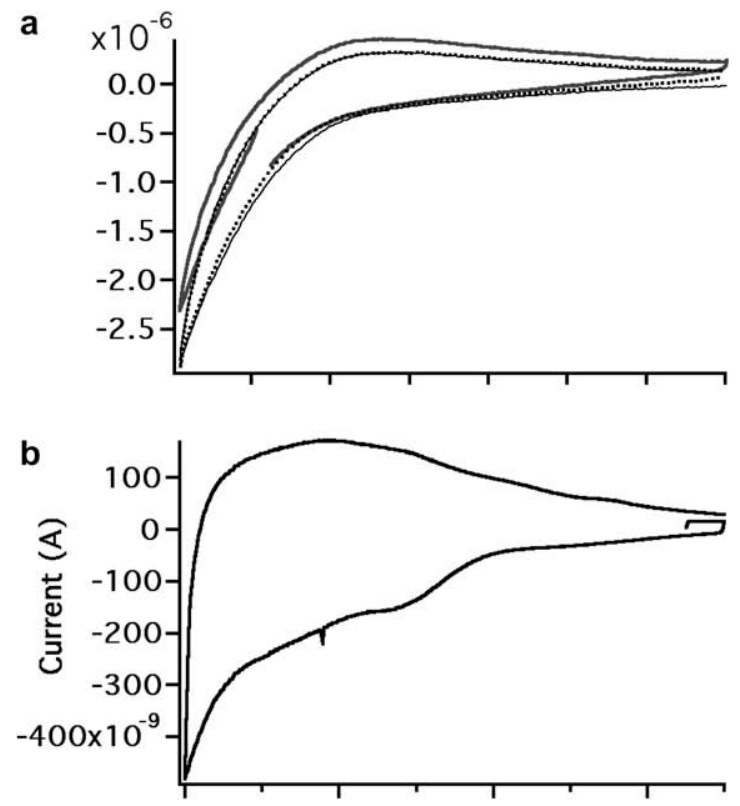

C

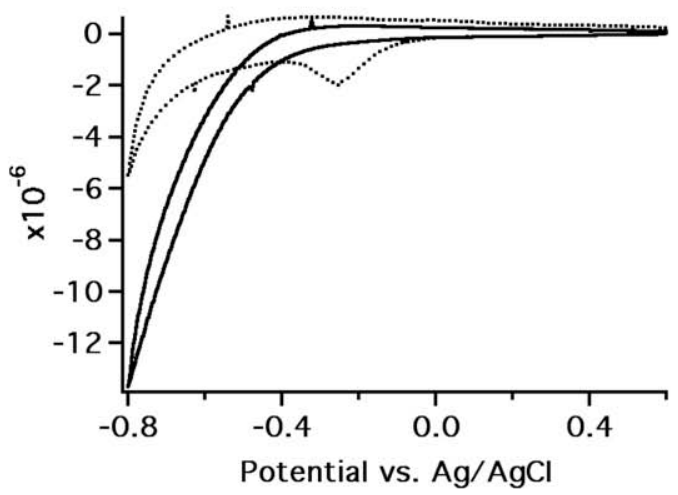

Fig. 2. (a) A control experiment in oxygen-saturated $10 \mathrm{mM} \mathrm{KCl}$ solution. A CV scan from $+0.6 \mathrm{~V}$ to $-0.8 \mathrm{~V}$ and back to $+0.6 \mathrm{~V}$ vs. $\mathrm{Ag} / \mathrm{AgCl}$ produced no artifactual peak (thin solid line). Holding the potential at $+0.6 \mathrm{~V}$ for five minutes prior to the $\mathrm{CV}$ scan (dotted line) also did not produce artifactual peaks. A 5-min hold at $-0.55 \mathrm{~V}$ (notice discontinuity) also produced no artifactual peaks in the subsequent $\mathrm{CV}$ scan from $-0.6 \mathrm{~V}$ to $-0.8 \mathrm{~V}$, up to $+0.6 \mathrm{~V}$, and back to $-0.6 \mathrm{~V}$. (b) A small peak occurred at $-0.25 \mathrm{~V}$ in solutions purged with nitrogen; the resulting current was less than $0.1 \mu \mathrm{A}$, much smaller than peaks observed in other experiments. (c) In an experiment designed to produce an artifactual peak, with dissolved $\mathrm{O}_{2}$, no peaks were observed in $\mathrm{CV}$ scans (solid). When the electrode was scanned to negative potentials after an extensive purge with $\mathrm{N}_{2}$ (described in the text), a cathodic peak occurred at $-257 \mathrm{mV}$ vs. $\mathrm{Ag} / \mathrm{AgCl}$ (dotted) along with a small anodic peak at $+17 \mathrm{mV}$.

2006). These cytochromes retain their native lipid binding site as described in Eggleston et al. (2008).

\subsection{Electrode cleaning}

The hematite electrodes were from Tarascon sur Ariege, France. They were cleaned with a 2:1 solution of distilled deionized (DI) water and nitric acid that was heated to a light boil ( $\sim 94{ }^{\circ} \mathrm{C}$ in Laramie, Wyoming). The crystals were then rinsed with DI water twice and put into a $10 \mathrm{mM}$
Table 1

Bacteria and proteins used in this study with their origin and notation.

\begin{tabular}{|c|c|c|}
\hline & Notation & Origin \\
\hline \multicolumn{3}{|l|}{ Bacteria } \\
\hline $\begin{array}{l}\text { S. oneidensis MR-1 } \\
\text { (wild-type, ATCC 700550) }\end{array}$ & MR-1 & ATCC \\
\hline $\begin{array}{l}\text { S. oneidensis omc A } \\
\text { deletion (mutant) }\end{array}$ & $\triangle o m c A$ & PNNL \\
\hline $\begin{array}{l}\text { S. oneidensis mtrC } \\
\text { deletion (mutant) }\end{array}$ & $\Delta m t r C$ & PNNL \\
\hline $\begin{array}{l}\text { S. oneidensis mtr } C \text { and } \\
\text { omc } A \text { deletion (mutant) }\end{array}$ & $\Delta m \operatorname{tr} C-\Delta o m c A$ & PNNL \\
\hline \multicolumn{3}{|l|}{ Proteins } \\
\hline $\begin{array}{l}\text { MtrC (c-type cytochrome, } \\
\text { SO1778) }\end{array}$ & MtrC & $\begin{array}{l}\text { From } S \text {. oneidensis } \\
\text { MR-1 purified } \\
\text { at PNNL }\end{array}$ \\
\hline $\begin{array}{l}\text { OmcA ( } c \text {-type cytochrome, } \\
\text { SO1779) }\end{array}$ & OmcA & $\begin{array}{l}\text { From } S \text {. oneidensis } \\
\text { MR-1 purified } \\
\text { at PNNL }\end{array}$ \\
\hline
\end{tabular}

$\mathrm{NaOH}$ solution that was then heated until slightly bubbling. The crystals were again rinsed twice with DI water. After cleaning, crystals were air-dried and wrapped in Kim-wipes and stored until ready for use. Storage times for clean crystals ranged from a few days to a few weeks (Eggleston et al., 2003).

\subsection{Bacterial growth and cell suspensions}

All glassware, solutions and media were sterilized prior to use. MR-1 was cultured aerobically in TSB (tryptic soy broth) with shaking or anaerobically in modified GS-15 medium, which was made as described in Kostka and Nealson (1998) except that we used lactate as the electron donor, $\mathrm{Fe}(\mathrm{III})$-citrate as electron acceptor, added the mixed amino acids used for M-1 medium (Kostka and Nealson, 1998), used $0.3 \mathrm{~g} / \mathrm{L} \mathrm{NaOH}$ instead of $2.5 \mathrm{~g} / \mathrm{L} \mathrm{NaHCO}_{3}$, and used piperazine-1,4-bis(2-ethanesulfonic acid) (PIPES) as buffer. Both anaerobic and aerobic cultures were started from replicate frozen stock cultures. The mutants were grown aerobically in TSB for approximately $20 \mathrm{~h}$.

Cultures were started from replicate frozen stocks and incubated either 18-20 h (aerobic) or 46-48 h (anaerobic). Cells were harvested by centrifugation, washed with physiologic saline $(8.5 \mathrm{mM} \mathrm{NaCl})$, centrifuged and resuspended in $10 \mathrm{mM}$ MOPS (3-[N-Morpholino] propanesulfonic acid, $\mathrm{pH} 7$ ) and $8.5 \mathrm{mM} \mathrm{NaCl}$. Cell numbers were quantified by acridine orange direct counts (AODC). For each experiment, the starting cell density was $10^{7}$ cells $\mathrm{mL}^{-1}$.

\subsection{Protein films}

Protein films were made on individual hematite crystals. As-received protein solutions were buffer exchanged into $10 \mathrm{mM}$ MOPS and $10 \mathrm{mM} \mathrm{NaCl}$ using YM-10 Microcon centrifugal filters. Hematite crystals were dipped into a protein solution, and the film was allowed to form for 40 $60 \mathrm{~min}$ in a nitrogen atmosphere to ensure maximum sorption to the crystal surface (Eggleston et al., 2008). Protein concentrations were not measured directly in order to 
conserve protein; a previous measurement allowed us to estimate the protein concentration as between $0.15 \mathrm{mg} \mathrm{mL}^{-1}$ and $0.25 \mathrm{mg} \mathrm{mL}^{-1}$ based on color density. Under these conditions, at least $330 \mathrm{ng} \mathrm{cm}^{-2}$ adsorbs to the electrode surface, and little protein desorbs under dilution (Eggleston et al., 2008). The films were then removed from solution, and cyclic voltammetry $(\mathrm{CV})$ was run in a protein-free solution (10 mM MOPS, $10 \mathrm{mM} \mathrm{NaCl}$ ) under a nitrogen atmosphere. Protein films on hematite electrodes were stored in a freezer $\left(-20^{\circ} \mathrm{C}\right)$ between experiments.

\subsection{Voltammetry}

We used a 3-electrode electrochemical cell with a Pt wire counter electrode, an $\mathrm{Ag} / \mathrm{AgCl}$ reference electrode (Microelectrode, Inc.), and a hematite working electrode. An EG\&G 263A potentiostat was used for cyclic voltammetry (CV). The hematite electrodes varied in size and shape, but were about $5 \mathrm{~mm} \times 2 \mathrm{~mm}$ in area and roughly $0.5 \mathrm{~mm}$ thick (up to $50 \%$ variation in exposed electrode area is estimated). Electrodes were immersed about $1-2 \mathrm{~mm}$ in $2.5 \mathrm{~mL}$ of liquid contained in a $3 \mathrm{~mL}$ crucible. For anaerobic experiments, solutions were pre-purged by sparging with nitrogen for several hours prior to experiments. The $3 \mathrm{~mL}$ crucible was in turn encased in a $\sim 300 \mathrm{~mL}$ glass container that was continuously purged with $\mathrm{N}_{2}$ gas. In each experiment, control scans were taken before introduction of the experimental solution or cell suspension. CV was run on washed cells in buffered solution immediately after washing or within 1-2 h of preparation. As shown in the results, in some cases solutions were purged of oxygen prior to the experiment, and in some cases purging took place during the experiment in order to monitor the effect of purging. Each case is noted in the results or in figure captions.

\subsection{Peak potentials, midpoint potentials, and scaling}

Midpoint potentials $\left(E^{0 \prime}\right)$ were calculated from cathodic and anodic peak positions ( $E^{\mathrm{pc}}$ and $E^{\mathrm{pa}}$, respectively) by $E^{0 \prime}=\left(E^{\mathrm{pc}}+E^{\mathrm{pa}}\right) / 2$. $E^{0 \prime}$ values are not thermodynamically well defined (we do not know the activity of the oxidized and reduced species precisely) and may thus differ from a thermodynamically defined redox potential $\left(E^{0}\right)$.

Linear background subtractions were applied to the CV data. Nonlinear background subtractions are possible, but because of differences in working electrode area and doping level (which determines the magnitude of capacitive currents at a given scan rate) between different electrodes, linear background subtractions were applied to all data equally in order to avoid arbitrariness in the choice of parameters governing nonlinear background subtractions.

We used hematite as a working electrode because, as a nominally ferric oxide, it is the only material that is both similar to materials used as respiratory electron acceptors in natural systems and is also sufficiently conductive to be used as an electrode. A drawback of using iron oxide as a working electrode, however, is that when $E<E_{\mathrm{FB}}$, reductive dissolution can occur. This introduces redox-active Fe into the solution. This typically only occurs to a signif- icant extent in oxygen-purged solutions, but such conditions are important in the experiments reported here. Therefore, it is necessary to account for such "artifactual" iron in our data analysis.

\section{RESULTS}

\subsection{Controls}

Because of the possibility of reductive dissolution of the hematite electrode, we ran an extensive set of control scans in the absence of proteins or cells. Fig. 2 a shows the result of a control experiment in an oxygen-saturated $10 \mathrm{mM} \mathrm{KCl}$ solution; an initial CV scan, and CV scans taken after 5-min "holds" at $+0.6 \mathrm{~V}$ and $-0.55 \mathrm{~V}$, did not produce any artifactual peaks. In solutions purged of oxygen, we observed a very small cathodic peak at $-0.25 \mathrm{~V}$ in a few of the scans (Fig. 2b). Control experiments that were run for over an hour without oxygen, and using an initial "hold" at positive potential $(+0.50 \mathrm{~V}$ vs. $\mathrm{Ag} / \mathrm{AgCl})$ to oxidize reduced species in solution, revealed a pronounced cathodic peak at about $-0.25 \mathrm{~V}$ (data not shown; see Fig. 2c for similar data). The controls showed that the hematite electrodes can be reductively dissolved at the most negative potentials used in our experiments, leading to a release of redox-active iron that produces artifactual redox peaks not attributable to adsorbed protein or organisms.

Hematite electrodes were immersed in sterile proteinfree $10 \mathrm{mM}$ MOPS and $10 \mathrm{mM} \mathrm{NaCl}(\mathrm{pH} 7)$. In the presence of dissolved $\mathrm{O}_{2}$, no peaks were observed in $\mathrm{CV}$ scans (Fig. 2c). $\mathrm{N}_{2}$ gas was then introduced and the cell was purged for $25 \mathrm{~min}$, taking a $50 \mathrm{mV} \mathrm{s}^{-1} \mathrm{CV}$ scan every 5 min to monitor for the appearance of cathodic peaks. A series of $\mathrm{CV}$ scans at increasing scan rate from 50 to $800 \mathrm{mV} \mathrm{s}^{-1}$ were then taken, with 10 and $30 \mathrm{~s}$ "hold" times prior to each scan during which the electrode was held at $+0.50 \mathrm{~V}$ (the $10 \mathrm{~s}$ hold was done first, followed by the $30 \mathrm{~s}$ hold). This sequence of scans was used in all of the experiments reported below. After $5 \mathrm{~min}$ in an $\mathrm{N}_{2}$ atmosphere, a small cathodic peak appeared, similar to those seen in previous CV of protein-free solutions. This cathodic peak became more pronounced with time under $\mathrm{N}_{2}$; a cathodic peak occurred at $-257 \mathrm{mV}$ (Fig. 2c) along with a small anodic peak at $+17 \mathrm{mV}\left(E^{0 \prime}=-120 \mathrm{mV}\right)$ vs. $\mathrm{Ag} /$ $\mathrm{AgCl}$ (Table 2). By the reaction

$\mathrm{Fe}_{2} \mathrm{O}_{3}+2 \mathrm{e}^{-}+6 \mathrm{H}^{+}=2 \mathrm{Fe}^{2+}+3 \mathrm{H}_{2} \mathrm{O}$

this potential would require an $\mathrm{Fe}^{2+}$ (aq) activity of only $10^{-8.26}$, which is unrealistically low (most prepared solutions contain at least this much $\mathrm{Fe}$ as an impurity). If $E_{\mathrm{FB}}$ is about $-0.3 \mathrm{~V}$ at $\mathrm{pH} 7, E^{0 \prime}$ in Fig. 2c is less than $0.2 \mathrm{~V}$ positive of $E_{\mathrm{FB}}$, and thus about $0.4 \mathrm{~V}$ positive of the hematite conduction band edge. This value is comparable to pseudo-Fermi-level values reported for lepidocrocite and goethite relative to hematite (Leland and Bard, 1987), prompting us to speculate that a surface layer of hydroxide-like material may mediate charge transfer between hematite and the electrolyte solution. Negative potentials $\left(<E_{\mathrm{FB}}\right)$ lead to slow dissolution of $\mathrm{Fe}^{2+}$; subsequent oxidation of $\mathrm{Fe}^{2+}$ near the hematite electrode surface during 
Table 2

Peak positions and midpoint potentials (vs. $\mathrm{Ag} / \mathrm{AgCl}$ ) at a scan rate of $50 \mathrm{mV} \mathrm{s}^{-1}$ for raw data (labeled "raw") prior to accounting for dissolved iron in data analysis, and after background and control subtraction.

\begin{tabular}{|c|c|c|c|c|}
\hline & $\begin{array}{l}E^{\mathrm{pc}} \\
(\mathrm{mV})\end{array}$ & $\begin{array}{l}E^{\mathrm{pa}} \\
(\mathrm{mV})\end{array}$ & $\begin{array}{l}E^{0 \prime} \\
(\mathrm{mV})\end{array}$ & Reference \\
\hline Control & -257 & +17 & -120 & This study \\
\hline MtrC (raw) & -303 & +6 & -149 & $"$ \\
\hline OmcA (raw) & -302 & -77 & -189 & $"$ \\
\hline OmcA & -331 & -71 & -201 & $"$ \\
\hline OmcA & -380 & 60 & -160 & $\begin{array}{l}\text { Eggleston et al. } \\
(2008)\end{array}$ \\
\hline MtrC & -329 & +3 & -163 & $"$ \\
\hline $\mathrm{MtrC}$ & -297 & -237 & -267 & $\begin{array}{l}\text { Hartshorne et al. } \\
\text { (2007) }\end{array}$ \\
\hline $\begin{array}{l}\text { MR-1 (raw- } \\
\text { a) }\end{array}$ & -329 & -17 & -173 & This study \\
\hline $\begin{array}{l}\text { MR-1 (raw- } \\
\text { b)Q1 }\end{array}$ & -368 & -59 & -214 & $"$ \\
\hline IR-1 & -298 & 18 & -140 & Kim et al. (1999) \\
\hline MR-1 & -351 & 79 & -136 & Kim et al. (2002) \\
\hline MR-1 & -344 & -22 & -183 & $\begin{array}{l}\text { Cho and Ellington } \\
\text { (2007) }\end{array}$ \\
\hline$\Delta m \operatorname{tr} C(\mathrm{raw})$ & -280 & -80 & -180 & This study \\
\hline$\Delta m t r C$ & -306 & -77 & -192 & $"$ \\
\hline$\Delta o m c A$ (raw) & -291 & -20 & -156 & $”$ \\
\hline$\Delta o m c A$ & -309 & -9 & -159 & $"$ \\
\hline $\begin{array}{l}\Delta m \operatorname{tr} C- \\
\Delta o m c A\end{array}$ & -257 & +17 & -120 & $"$ \\
\hline
\end{tabular}

"holds" at $+0.5 \mathrm{~V}$ could lead to rapid precipitation of $\mathrm{Fe}^{3+}$ as a thin ferrihydrite-like surface layer. By the reaction

$\mathrm{Fe}(\mathrm{OH})_{3}+3 \mathrm{H}^{+}+\mathrm{e}^{-}=\mathrm{Fe}^{2+}+3 \mathrm{H}_{2} \mathrm{O}$

an $\mathrm{Fe}^{2+}{ }_{\text {(aq) }}$ activity of $10^{-4.43}$ is required in order to achieve the $E^{0 \prime}$ observed in Fig. 2c (e.g., (Drever, 1997), which is more realistic given the currents observed. The existence of a thin $\mathrm{Fe}(\mathrm{OH})_{3}$ layer at the hematite surface is supported

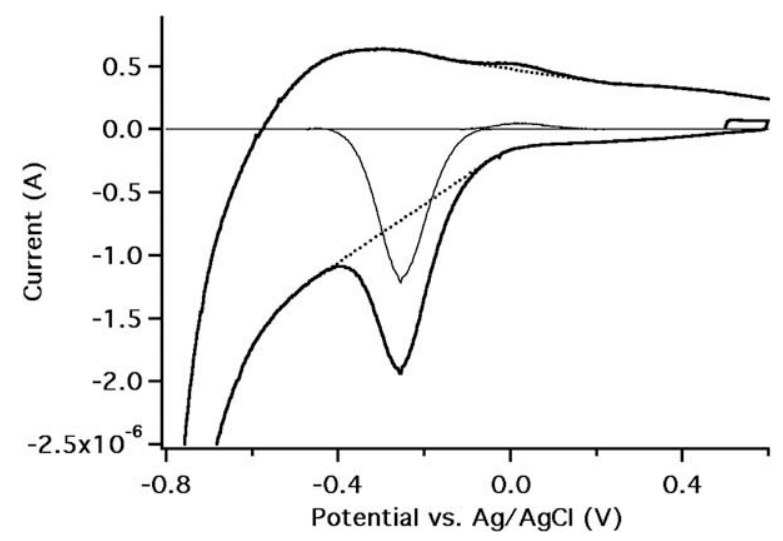

Fig. 3. The voltammogram in Fig. 2c is shown here (thick solid) with a linear background (dotted) that can be subtracted to give the no-background peaks (thin solid). This background subtraction procedure was used on all of our data presented below in order to put all of the data on an equal footing. by the scan-rate dependence of current (data presented below).

In the presentation of results to follow, the control CV scan in Fig. 2c is included for comparison. We caution that because the hematite electrodes were not all the same size, variations in current from experiment to experiment are expected. Fig. 3 shows the control scan from Fig. 2c as well as the result of linear background subtraction; the background-subtracted scan was used in the interpretation of results presented below, and was scaled to account for variations in electrode properties. Note that the redox reaction in Fig. 3 is irreversible such that the cathodic peak is far larger than the anodic peak. This is partly due to the rectifying behavior of the semiconducting hematite electrode, but the anodic peak current also varies considerably between proteins and organisms (see results below).
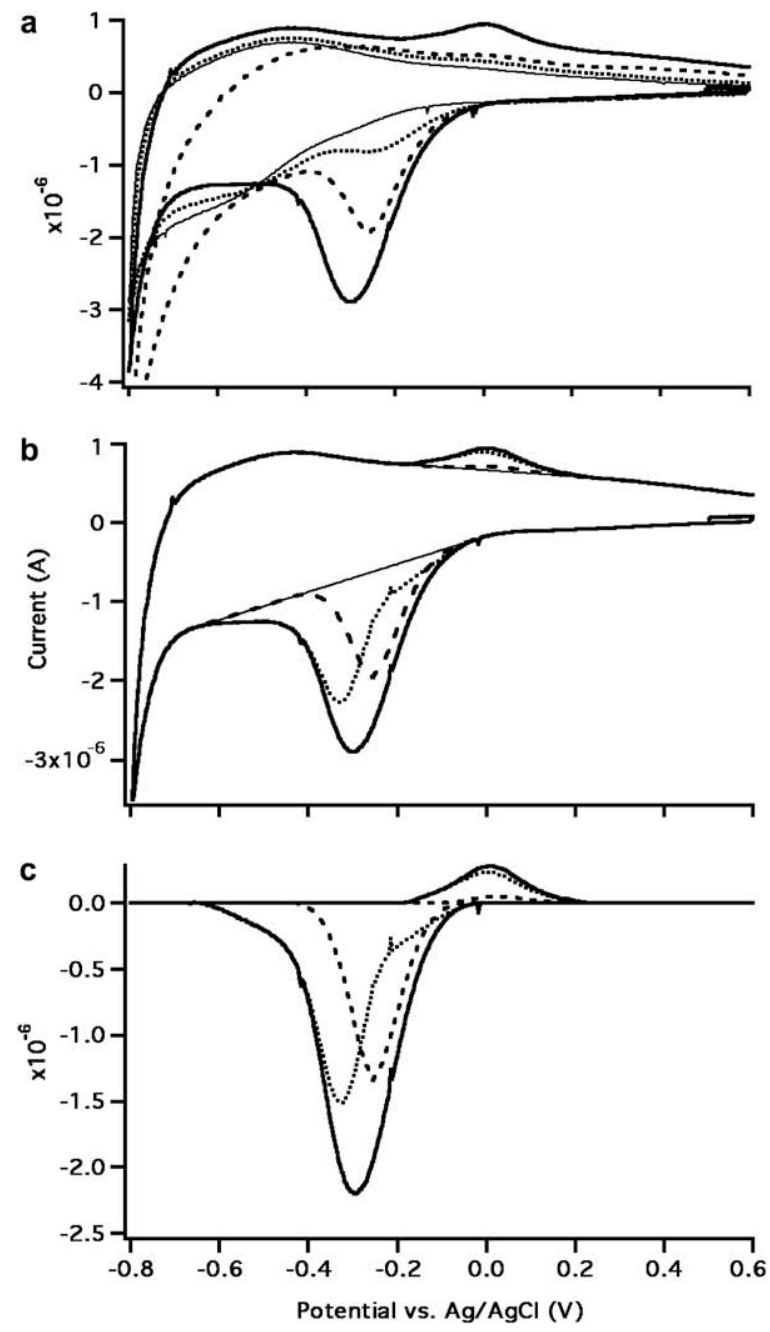

Fig. 4. (a) CV scans for an MtrC-coated hematite electrode after a $10 \mathrm{~s}$ hold at $+500 \mathrm{mV}$ (thin solid), an initial $30 \mathrm{~s}$ hold at $+500 \mathrm{mV}$ (dotted), and a final $30 \mathrm{~s}$ hold at $+500 \mathrm{mV}$ (thick solid). The dashed line is the control scan representing Fe dissolved from the electrode. (b) The final $30 \mathrm{~s}$ hold scan from (a) with a linear background, a scaled contribution from "artifactual" Fe (dashed, scaling factor 1.1) and a residual peak (dotted) tentatively attributed to MtrC. (c) the same peaks as shown in (b), after background subtraction. 


\subsection{Protein film voltammetry}

$\mathrm{CV}$ of protein films was conducted in a $\mathrm{N}_{2}$ atmosphere. Sterilized protein-free solutions were first purged of oxygen and then put into the cell in the gas flow chamber. In order to oxidize any reduced protein at the hematite surface, we used hold times at an electrode potential of $+0.50 \mathrm{~V}$ vs. $\mathrm{Ag} / \mathrm{AgCl}$. Longer hold times, presumably through oxidation of both protein and of any $\mathrm{Fe}^{2+}$ on or near the surface, led to increased cathodic and anodic peak currents. For example, in Fig. 4, data for a $10 \mathrm{~s}$ hold at $+0.50 \mathrm{mV}$, the first $30 \mathrm{~s}$ hold, and the last $30 \mathrm{~s}$ hold reflect increasing peak currents with increasing hold times, and are compared to the raw data for a protein-free control scan.

For the MtrC film (Fig. 4), $E^{\mathrm{pc}}=-303 \mathrm{mV}$ and $E^{\text {pa }}=+6 \mathrm{mV}$, giving $E^{0 \prime}=-149 \mathrm{mV}$ vs. $\mathrm{Ag} / \mathrm{AgCl}$ (Table 2). For the OmcA-film (Fig. 5), $E^{\mathrm{pc}}=-302 \mathrm{mV}$ and $E^{\mathrm{pa}}=-77 \mathrm{mV}$, which gives $E^{0 \prime}=-189 \mathrm{mV}$ vs. $\mathrm{Ag} / \mathrm{AgCl}$ (Table 2). These $E^{0 \prime}$ values are for the system as a whole and include contributions from both the protein and probably from dissolved or surface-bound "artifactual" Fe. In Fig. 4b, the MtrC linear background is shown along with data from a control scan and a "residual" peak attributed to $\mathrm{MtrC}$; the same peaks, after background subtraction, are shown in Fig. 4c and add up to the peak in the raw data. For the residual peak attributed to $\mathrm{MtrC}$, the $E^{\mathrm{pc}}$ and $E^{\mathrm{pa}}$ values are -329 and $3 \mathrm{mV}$ vs. $\mathrm{Ag} / \mathrm{AgCl}$, respectively, giving $E^{0 \prime}=-163 \mathrm{mV}$. In Fig. 5, for the OmcA film, the residual $E^{\mathrm{pc}}$ and $E^{\mathrm{pa}}$ values are -331 and $-71 \mathrm{mV}$, respectively,
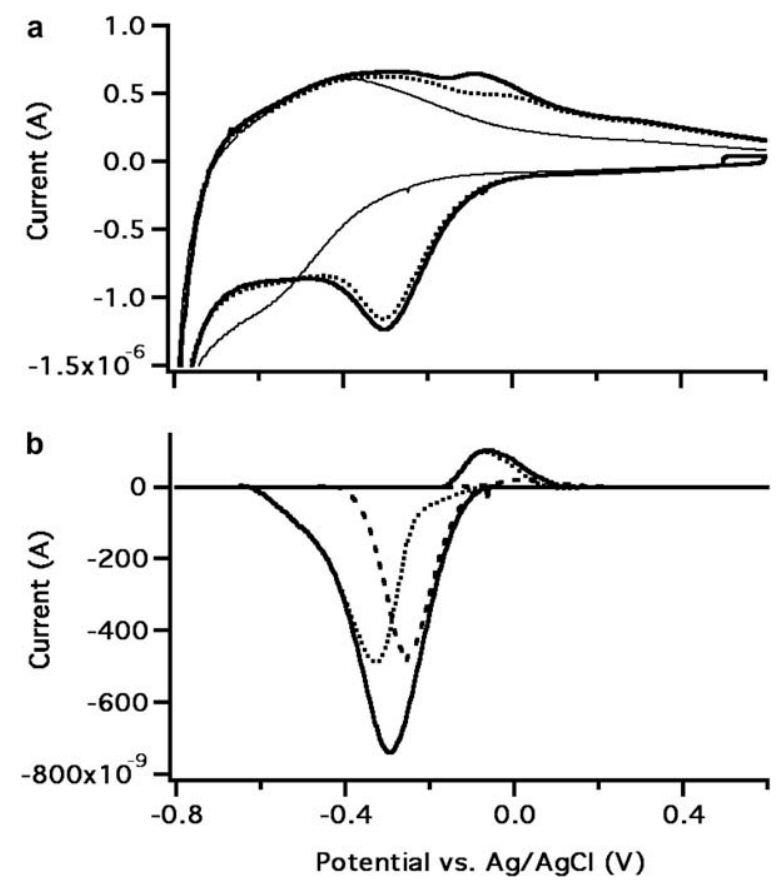

Fig. 5. (a) CV scans for an OmcA-coated hematite electrode after a $10 \mathrm{~s}$ hold (thin solid), initial $30 \mathrm{~s}$ hold (dotted), and final $30 \mathrm{~s}$ hold (thick solid) at $+500 \mathrm{mV}$ prior to each scan. (b) Control (dashed; scaling factor $=0.35$ ) and residual (dotted) peaks after background subtraction. The residual (dotted) peaks are tentatively attributed to OmcA. giving $E^{0 \prime}=-201 \mathrm{mV}$. For comparison, Eggleston et al. (2008) reported $E^{0 \prime}$ for OmcA of $-208 \mathrm{mV}$ vs. $\mathrm{Ag} / \mathrm{AgCl}$.

There are several aspects of Figs. 4 and 5 that should be emphasized. The anodic peak current is much higher for the protein films than for the controls, relative to the cathodic peak current, in each case. For OmcA, the anodic peak position is also more negative than that of $\mathrm{MtrC}$ or $\mathrm{Fe}$ from the electrode. The size of the "artifactual" (control) cathodic peak has been scaled to fit under the raw peak shape and to give a reasonable peak shape to the residual peak that we tentatively attribute to adsorbed protein. The scaling factor is subjective because we have no a priori way of knowing how much of each raw peak can be attributed to artifactual Fe from the electrode, and how much to the adsorbed protein (though we note that the total number of electrons attributed to current from the hematite electrode to the adsorbed protein is smaller than the number of hemes in adsorbed protein).

\subsection{Shewanella oneidensis MR-1 voltammetry}

$\mathrm{CV}$ was performed on washed cell suspensions of the wild-type MR-1 as described in Section 3.1. Fig. 6 compares our CV data for MR-1 (after subtraction of the artifactual Fe signal) to CV data from Kim et al. (1999a) for Shewanella putrefaciens IR-1 under anaerobic conditions (glassy carbon electrode), from Kim et al. (2002) for $S$. oneidensis MR-1 (glassy carbon electrode), and Cho and Ellington (2007) for $S$. oneidensis MR-1 (graphite electrode). Our data using hematite electrodes compares very well with data from these other studies. $E^{\mathrm{pc}}, E^{\mathrm{pa}}$, and $E^{0 \prime}$ values for all of the studies (raw data) are given in Table 2. We include our background-subtracted data for both $50 \mathrm{mV} \mathrm{s}^{-1}$ and $100 \mathrm{mV} \mathrm{s}^{-1}$ scan rates for comparability with the other work done at $100 \mathrm{mV} \mathrm{s}^{-1}$ scan rate.

We prepared cultures of $S$. oneidensis MR-1 under both aerobic and anaerobic conditions. Cathodic and anodic

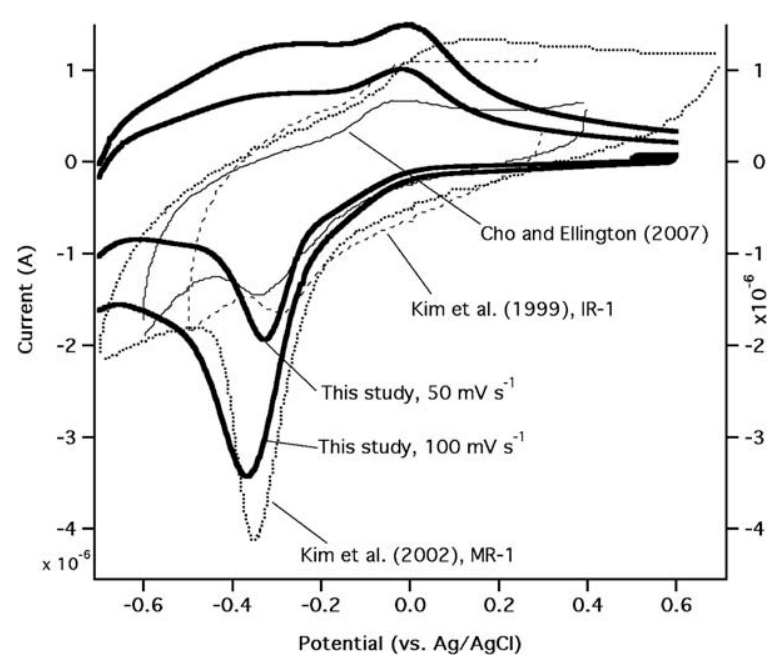

Fig. 6. Background-subtracted CV data for wild-type Shewanella oneidensis MR-1 under anaerobic conditions, at $50 \mathrm{mV} \mathrm{s}^{-1}$ (thick gray) and $100 \mathrm{mV} \mathrm{s}^{-1}$ (thick black) scan rates, compared with $100 \mathrm{mV} \mathrm{s}^{-1}$ data from other studies. 
peaks like those in Fig. 6 were only observed for anaerobic conditions within the electrochemical cell, whether or not the original cells were grown aerobically or anaerobically. Redox peaks were not observed for anaerobically prepared cultures if they were subsequently observed in an aerobic electrochemical cell (data not shown), but were observed for aerobically prepared cultures after purging the electrochemical cell of oxygen for 20-30 min (Fig. 7). CV scans for an initial $10 \mathrm{~s}$ hold, the first $30 \mathrm{~s}$ hold, and the last $30 \mathrm{~s}$ hold (following the sequence of $\mathrm{CV}$ scans outlined above) are shown in Fig. 7a. After the initial $10 \mathrm{~s}$ hold, there is a small cathodic peak at $-251 \mathrm{mV}$ vs. $\mathrm{Ag} / \mathrm{AgCl}$, almost exactly as expected for Fe dissolved from the hematite electrode. After holding at $+0.50 \mathrm{~V}$ to oxidize species adsorbed to the surface, the other two CV scans in Fig. 7a were observed at a more negative potential. Fig. $7 \mathrm{~b}$ shows the linear background, a peak derived from "artifactual"
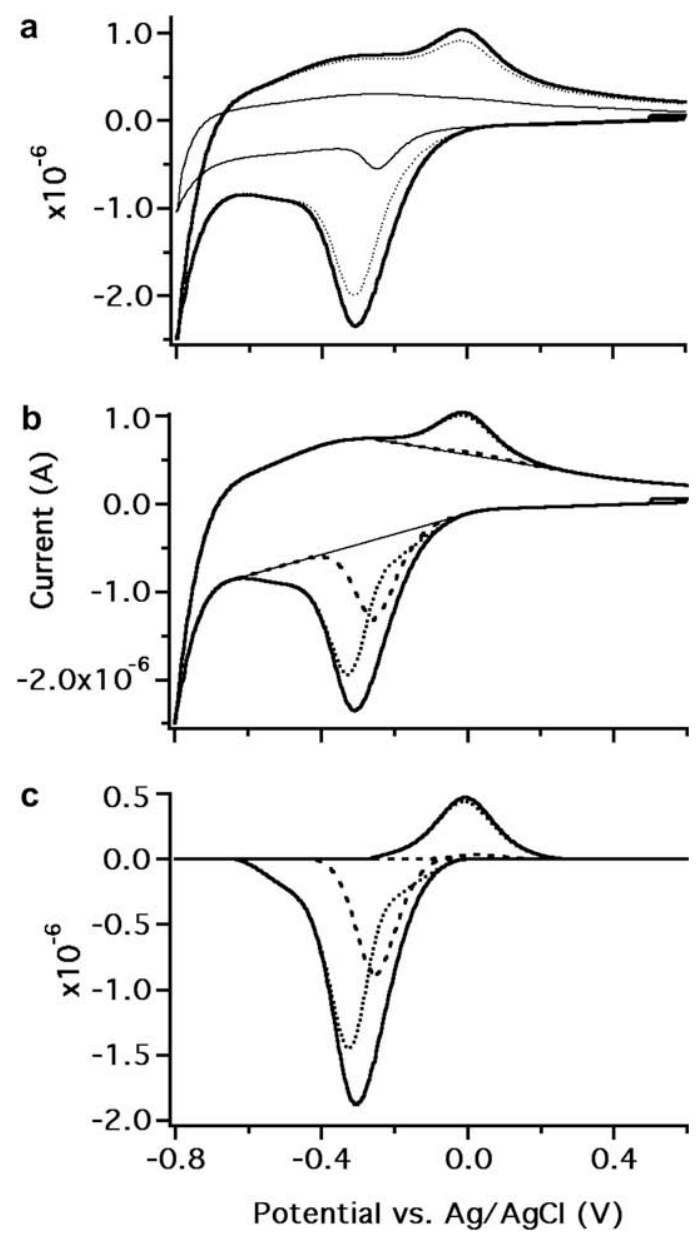

Fig. 7. Voltammograms of aerobically cultured Shewanella oneidensis MR-1 suspensions, $10^{7}$ cells $\mathrm{mL}^{-1}$. CV scans were taken during purging to remove oxygen. (a) $\mathrm{CV}$ scans after an initial $10 \mathrm{~s}$ hold at $+500 \mathrm{mV}$ (thin solid), after an initial $30 \mathrm{~s} \mathrm{hold} \mathrm{(dotted),} \mathrm{and}$ after the last $30 \mathrm{~s}$ hold (thick solid). (b) The last CV scan from (a) (thick solid in both panels) with a linear background (thin solid), a peak attributed to artifactual $\mathrm{Fe}$ (dashed, scaling factor 0.75 ), and a peak attributed to cells near the surface (dotted). (c) The same peaks as in part (b), after background subtraction.

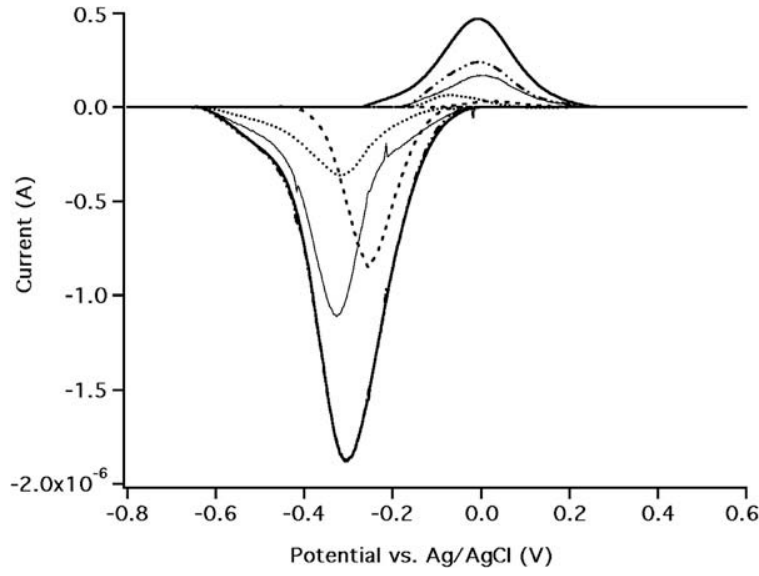

Fig. 8. Data from the control experiment showing artifactual $\mathrm{Fe}$ (dashed, scale factor 0.7), from the OmcA film (dotted, scale factor 0.64), and from the MtrC film (thin solid, scale factor 0.73). The sum of these contributions (dot-dash) fits the cathodic data closely. With this fit, however, the individual anodic currents from OmcA, $\mathrm{MtrC}$ and the control cannot describe the anodic current from the wild-type MR-1.

$\mathrm{Fe}$, and a peak attributed to the organism, along with the last $30 \mathrm{~s}$ hold CV from Fig. 7a; Fig. 7c shows the same peaks after background subtraction. The peak shown in a dotted line in Fig. $7 \mathrm{~b}$ is the same cathodic peak used in Fig. 6 for $50 \mathrm{mV} \mathrm{s}^{-1}$ scan rate. As with MtrC and OmcA, the anodic peak current in the presence of organisms is much greater than the anodic peak current associated with artifactual $\mathrm{Fe}$, even when normalized to the cathodic peak area.

It is reasonable to ask if the $\mathrm{CV}$ data for the MR-1 cells can be approximated using the data from the individual proteins plus that from artifactual Fe (Fig. 8). The cathodic peak can be matched almost exactly. The relative contributions from OmcA and MtrC to the cathodic peak are poorly constrained because both peak shapes are so similar that one peak could replace the other. The anodic peak for the MR-1 is much larger than can be explained by a sum of anodic currents from MtrC, OmcA and artifactual Fe dissolved from the electrode, given a good fit to the cathodic peak. OmcA contributes current to the anodic peak at a much more negative potential than does MtrC, and both OmcA and MtrC contribute more current than artifactual (presumably inorganic) Fe dissolved from the hematite electrode. We speculate that these two proteins work together, perhaps as a functional complex, to catalyze electron transfer to solid surfaces. Shi et al. (2006) observed 40\% greater catalytic activity of the OmcA-MtrC complex toward reduction of dissolved $\mathrm{Fe}(\mathrm{III})-\mathrm{NTA}$ than with either cytochrome individually. Our results are consistent with this observation, but apply to a solid Fe(III) electron acceptor.

\subsection{Voltammetry of mutants}

All experiments with mutant cell suspensions were conducted using solutions that were not pre-purged with $\mathrm{N}_{2}$ because it was hypothesized that different mutants would require different times to express outer membrane proteins. 
We monitored the appearance and growth of redox peaks in the voltammograms taken over time during purging, starting from an aerobic condition. A series of voltammograms were taken at scan rates and hold times using the same protocol as those completed for MR-1 and for the protein films.

We hypothesized that the double-deletion mutant $\Delta m \operatorname{tr} C-\Delta o m c A$ would be unable to catalyze electron transfer to and from the solid hematite electrode. $\mathrm{CV}$ results are given in Fig. 9; Fig. 9a shows the first $10 \mathrm{~s}$, first $30 \mathrm{~s}$, and last $30 \mathrm{~s}$ hold for $\Delta m t r C-\Delta o m c A$. The background-subtracted peaks for $\Delta m t r C-\Delta o m c A$ are indeed virtually identical to those for artifactual $\mathrm{Fe}$ dissolved from the hematite electrode (Fig. 9b). This holds true for all scan rates (data not shown). There is no evidence in the $\Delta m t r C-\Delta o m c A C V$ data for direct electron transfer between the hematite and any redox-active species other than Fe dissolved from the hematite electrode. This result is clearly different from the results for protein films and wild-type MR1. Bretschger et al. (2007) observed a small current, relative to controls, from the $\Delta \mathrm{mtrC}-\Delta$ omcA mutant in their microbial fuel cell experiments. In comparison, our experiments (a) did not contain a fuel, so little such current is expected, but in any case (b) the agreement between our control and our results for $\Delta \mathrm{mtrC}-\Delta \mathrm{omcA}$ is not so exact that a small difference can be excluded. Also, Bretschger et al. (2007) noted that the double deletion mutant could restore much of its reducing power after $24 \mathrm{~h}$, implying the activation of alternative pathways for electrode reduction. This is
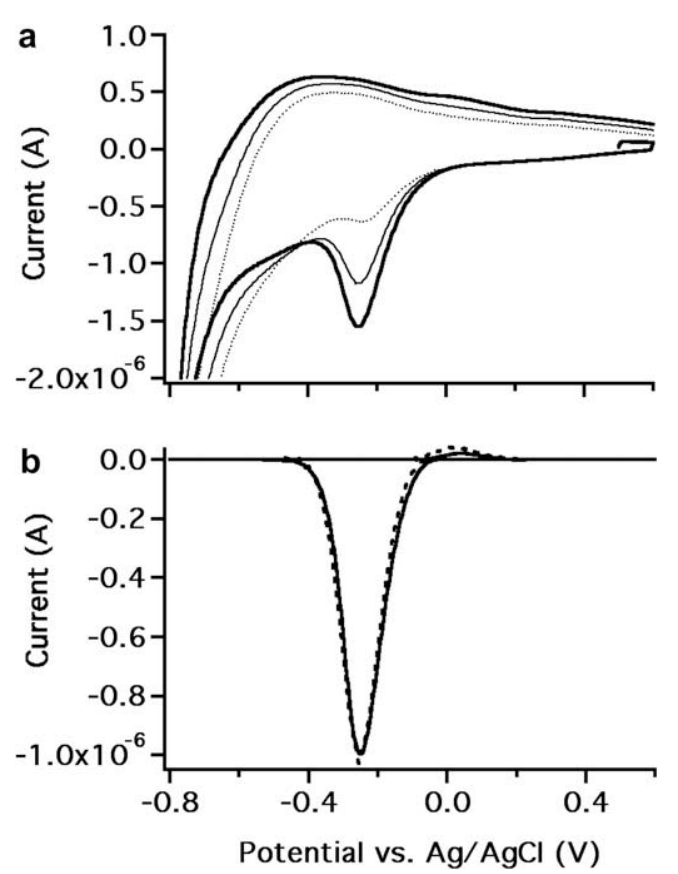

Fig. 9. (a) $\mathrm{CV}$ for $\Delta m t r C-\Delta o m c A$ under $\mathrm{N}_{2}$ purging. Initial scan after $10 \mathrm{~s}$ hold (dotted), first $30 \mathrm{~s}$ hold (thin solid), and last $30 \mathrm{~s}$ hold (thick solid); all holds at $+500 \mathrm{mV}$. (b) Background subtracted data from the last $30 \mathrm{~s}$ hold (solid) compared to $\mathrm{CV}$ of artifactual $\mathrm{Fe}$ (dashed). There is no evidence in the $\mathrm{CV}$ of $\Delta m t r C-$ $\triangle o m c A$ for electron transfer between hematite and any redox-active species other than $\mathrm{Fe}$ dissolved from the electrode. one reason our experiments were completed in well under $24 \mathrm{~h}$.

Fig. 10 shows results for $\Delta m t r C$; Fig. 10a shows the raw $\mathrm{CV}$ data and Fig. 10b shows the background-subtracted data composed of a component due to artifactual $\mathrm{Fe}$ (dashed) and a component due to another redox-active species. OmcA is still produced in $\Delta m t r C$ cultures. Fig. 10c shows the result for $\Delta m t r C$ compared to the result for the OmcA protein film. The cathodic peaks are similar, but the anodic current from $\Delta m t r C$ to hematite is larger than from OmcA to hematite. This suggests that OmcA on the surface of $\Delta m t r C$ cells behaves differently from the OmcA film, or that there is another redox-active agent associated with the $\Delta m t r C$ cells that is not present in $\Delta m t r C-\Delta o m c A$.

Fig. 11 shows results for $\triangle o m c A$ (which still produces $\mathrm{MtrC}$ ). Fig. $11 \mathrm{c}$ shows the result for $\Delta o m c A$ compared to the result for the MtrC protein film. Although the cathodic peak position is slightly different, the peak shapes and the relative sizes of the cathodic and anodic peaks are very
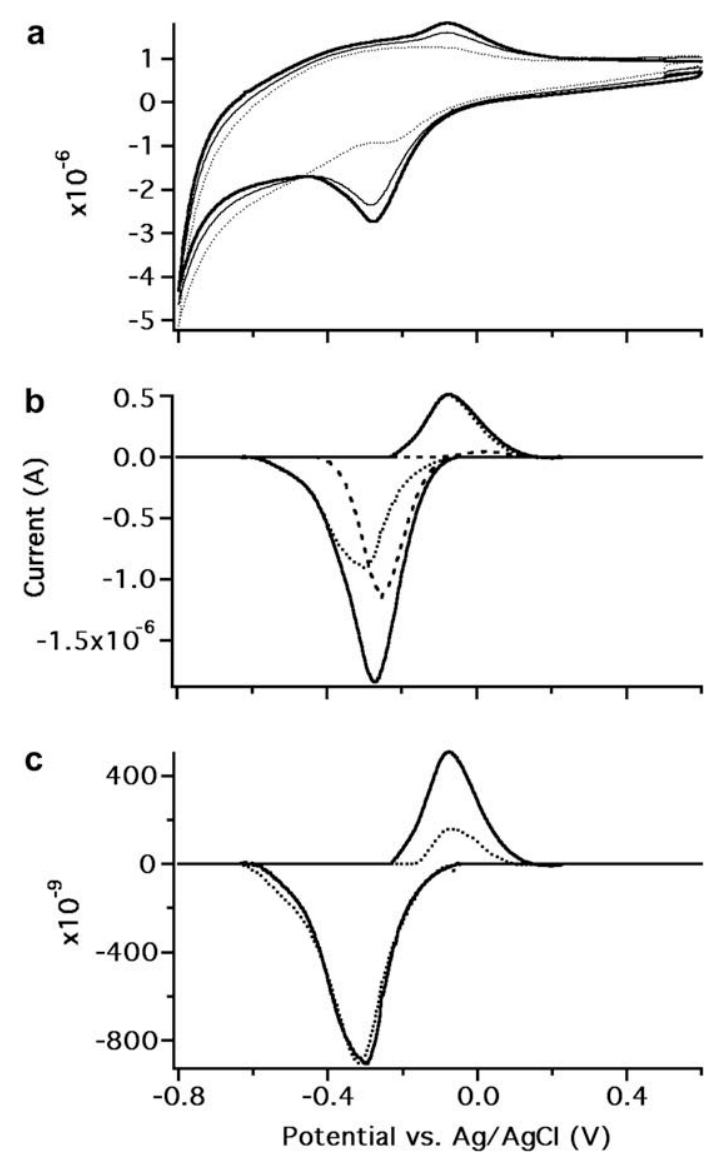

Fig. 10. (a) Raw CV data for $\Delta m t r C ; 10 \mathrm{~s}$ hold (thin dotted), $30 \mathrm{~s}$ hold (thin solid), last $30 \mathrm{~s}$ hold (thick solid); holds all at $+500 \mathrm{mV}$. (b) Last $30 \mathrm{~s}$ hold data, background subtracted, with a component for artifactual $\mathrm{Fe}$ from the electrode (dashed; scale factor 0.95) and a residual component tentatively attributed to the $\Delta m t r C$ mutant, presumably only carrying the OmcA but not MtrC protein. (c) The $\Delta m \operatorname{tr} C$ residual data tentatively attributed to OmcA (thick solid) compared to the OmcA film data (dotted). Cathodic current and peak shapes are similar, but the anodic current is smaller for the OmcA film than for $\Delta m \operatorname{tr} C$. 

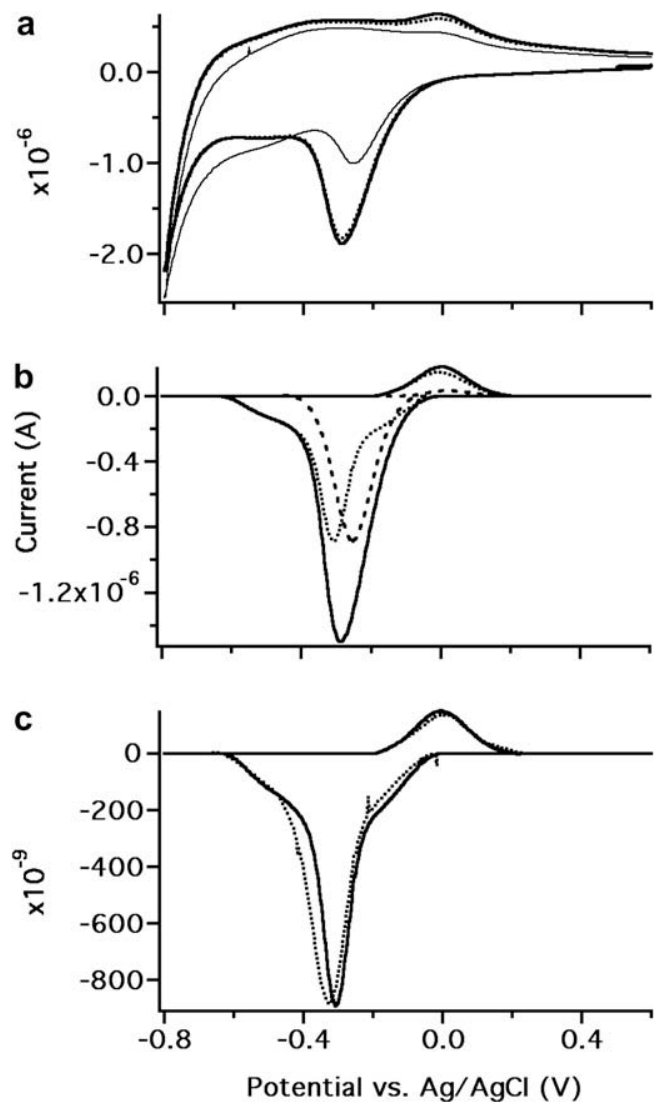

Fig. 11. (a) Raw CV data for $\Delta o m c A ; 10 \mathrm{~s}$ hold (thin solid), $30 \mathrm{~s}$ hold (dotted), last $30 \mathrm{~s}$ hold (thick solid); holds all at $+500 \mathrm{mV}$. (b) Last 30 s hold data, background subtracted, with a component for artifactual $\mathrm{Fe}$ from the electrode (dashed; scale factor 0.7) and a residual component tentatively attributed to $\Delta o m c A$, presumably only carrying the MtrC but not OmcA protein. (c) The $\Delta o m c A$ residual data tentatively attributed to $\mathrm{MtrC}$ (thick solid) compared to the MtrC film data (dotted). Peak shapes are similar, as are relative currents, although the cathodic peak position is slightly different.

similar and supportive of the notion that $\Delta o m c A$ still expresses MtrC to the outer membrane where it can interact with the hematite electrode.

\section{DISCUSSION}

\subsection{Voltammetric characteristics}

In previous studies (Khare et al., 2005, 2006a,b) with cytochrome $c$ (not from DMRB) and hematite electrodes, we observed redox peaks at the expected potentials for the native state of the protein and, under some circumstances (such as with the addition of denaturant), for unfolded states of the protein as well. Cytochrome $c$ could also be inactivated such that no redox peaks were observed. Thus, in voltammetry with hematite electrodes, there is precedent for expecting (a) that other redox-active proteins will exhibit expected redox potentials, and (b) that redoxinactive protein gives no redox peaks.
Table 3

Scan rate dependence of current (slope of linear current vs. scan rate).

\begin{tabular}{lll}
\hline $\begin{array}{l}\text { Bacteria or } \\
\text { protein }\end{array}$ & $\begin{array}{l}\text { Cath. slope, As/ } \\
\mathrm{V} \times 10^{-6}\end{array}$ & $\begin{array}{l}\text { An. slope, As/ } \\
\mathrm{V} \times 10^{-6}\end{array}$ \\
\hline Control & $-11.0(1.6)$ & $0.06(0.03)$ \\
$\Delta m t r C-\Delta o m c A$ & $-8.3(1.7)$ & $-0.04(0.02)$ \\
OmcA & $-6.6(0.7)$ & $-0.17(0.28)$ \\
MtrC & $-26.0(2.1)$ & $1.9(0.6)$ \\
$\Delta o m c A$ & $-8.5(1.8)$ & $0.67(0.07)$ \\
$\Delta m t r C$ & $-7.5(2.1)$ & $4.7(0.08)$ \\
MR-1 & $-9.1(1.6)$ & $1.6(0.3)$ \\
\hline
\end{tabular}

Values in parentheses are the uncertainties in slope from linear least-squares fits. The data from our highest scan rate $\left(0.8 \mathrm{~V} \mathrm{~s}^{-1}\right)$ was limited by the fact that the cathodic peak was wider than our scan range at negative potential. Peak currents, whose quantification requires background subtraction, could not be determined and thus we excluded the $0.8 \mathrm{~V} \mathrm{~s}^{-1}$ data.

Peak width and position as a function of scan rate contain useful information. For example, cathodic currents are a linear function of scan rate (Table 3), as expected for diffusionless electron exchange with adsorbed redox species. This observation forms the basis for concluding that the "artifactual" Fe occurs as a surface layer (see discussion of Fig. 2c). There is no evidence for a parabolic (concave upward) scan rate dependence characteristic of dissolved, diffusing redox species. In some cases the slope appears to decrease with increasing scan rate, which may be attributed to the well-known frequency-dependent space charge properties of hematite electrodes (e.g., Horowitz, 1983). The slopes are all the same within uncertainty, except the MtrC protein film with higher slope. Anodic peak currents (Fig. 12) are also linear-to-sublinear with scan rate.

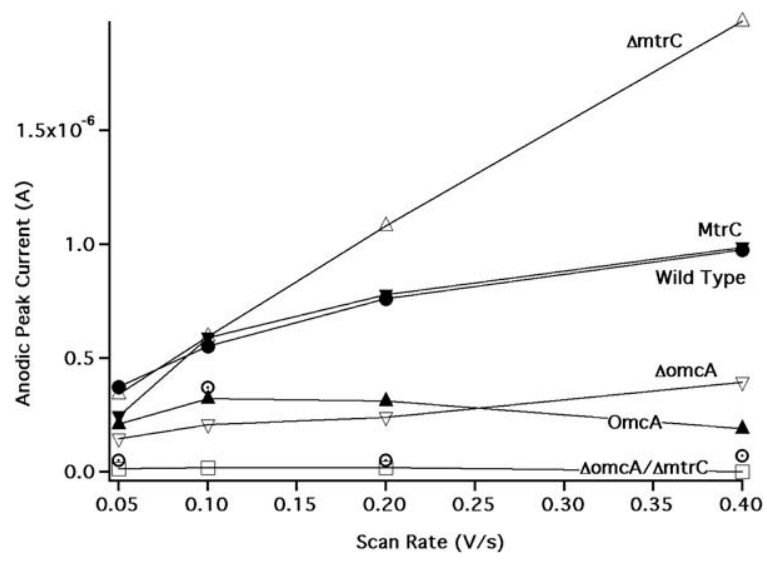

Fig. 12. Anodic peak current, after background subtraction, as a function of scan rate. If the redox-active molecules had been dissolved and subject to diffusion to or from the electrode surface, current would increase parabolically with scan rate. Linear scan rate dependence, in contrast, is consistent with a redox-active surface layer on the electrode. In this figure, currents are roughly linear (not parabolic), but are subject to attenuation at high scan rate- probably due to a combination of background-subtraction artifact combined with possible scan-rate dependent molecular properties. 
Absolute currents cannot be compared directly because of variation in electrode size and because protein concentrations and sorption densities were not necessarily the same in each case. In general, however, anodic slopes varied more than cathodic slopes. Anodic currents are generally much higher in the presence of proteins and organisms that are able to make at least one of either OmcA or MtrC. The variation in anodic slopes relative to the cathodic slopes is consistent with the interpretation that electron transfer to hematite is subject to different mechanistic controls than electron transfer from hematite.

In an ideal electrode reaction in which a layer of adsorbed molecules undergoes reversible oxidation and reduction, the peak width at half height is $0.304 T / n$ (Armstrong et al., 2000) where $T$ is in Kelvin and $n$ is the number of electrons. For $n=1$ (i.e., treating hemes individually within cytochromes), this is about $90.5 \mathrm{mV}$ at $25^{\circ} \mathrm{C}$. Our controls and $\Delta m t r C-\Delta o m c A$ cathodic peaks were 130 and $140 \mathrm{mV}$ wide, respectively, and all of our other raw data (attributed to at least two different electrochemical processes) had cathodic peak widths of $190-220 \mathrm{mV}$. After separating out the control contribution, the residual cathodic peaks had a width of 111-183 mV (i.e., broader than $90.5 \mathrm{mV}$ ). This is not surprising because there are many possibilities for kinetic dispersion (i.e., hemes exchanging electrons with the electrode at different energies and rates), blocking layers, and other effects in our system. For perfectly irreversible electron transfer with an adsorbed layer, cathodic peaks should be $62.5 / \alpha n \mathrm{mV}$ wide (Honeychurch and Rechnitz, 1998), which for $n=1$ and $\alpha=0.5$ equals $125 \mathrm{mV}$. This is closer to those that we observe, though our system is probably neither perfectly reversible nor perfectly irreversible.

\subsection{Kinetic analysis, Butler-Volmer}

Butler-Volmer (BV) theory is often used to extract rate constants from CV data (Armstrong et al., 1997, 2000; Hirst and Armstrong, 1998; Hartshorne et al., 2007). As background, the overpotential $\eta$ is the difference between $E^{0 \prime}$ and either $\mathrm{E}^{\mathrm{pc}}$ (giving the cathodic overpotential $\eta^{\mathrm{c}}$ ) or $E^{\mathrm{pa}}$ (giving the anodic overpotential $\eta^{\mathrm{a}}$ ). The Laviron equation relates the electron transfer rate constant $k$ to peak position for a layer of redox-active adsorbed molecules (Laviron, 1979; Honeychurch and Rechnitz, 1998):

$E^{\mathrm{pc}}=E^{0 \prime}-\left(\frac{R T}{\alpha n F}\right) \ln \left[\frac{\alpha}{m}\right] \quad$ where $m=\left(\frac{R T}{n F}\right)\left(\frac{k_{c}}{|v|}\right)$

$R, T$ and $F$ have their usual meanings, $n$ is the number of electrons, $k_{c}$ is the rate constant for cathodic electron transfer $\left(\mathrm{s}^{-1}\right), v$ is the scan rate $\left(\mathrm{V} \mathrm{s}^{-1}\right)$, and $\alpha$ is the transfer coefficient $\left(\alpha=0.5\right.$ when $\eta^{\mathrm{c}}=\eta^{\mathrm{a}}$ ). Because peak position is not affected by the limitation affecting the current data, we can use the $800 \mathrm{mV} \mathrm{s}^{-1}$ data for $E^{\mathrm{pc}}$. If $v>k$, the slope of a plot of $\eta^{\mathrm{c}}$ vs. $\log (v)$ should be $-2.3 R T / \alpha n F$ [or $-2.3 R T /(1-\alpha) n F$ for $\eta^{\mathrm{a}}$ plotted vs. $\left.\log (v)\right]$.

Fig. 13a shows $\eta^{\mathrm{c}}$ vs. $\log (v)$ for the control scans (with artifactual $\mathrm{Fe}$ ) and for $\Delta m t r C-\Delta o m c A$. The thick dotted line in Fig. 13a shows a best fit to the control data, with $\alpha=0.5$ and $k_{c}=0.093 \mathrm{~s}^{-1}$. If we assume that only the high-
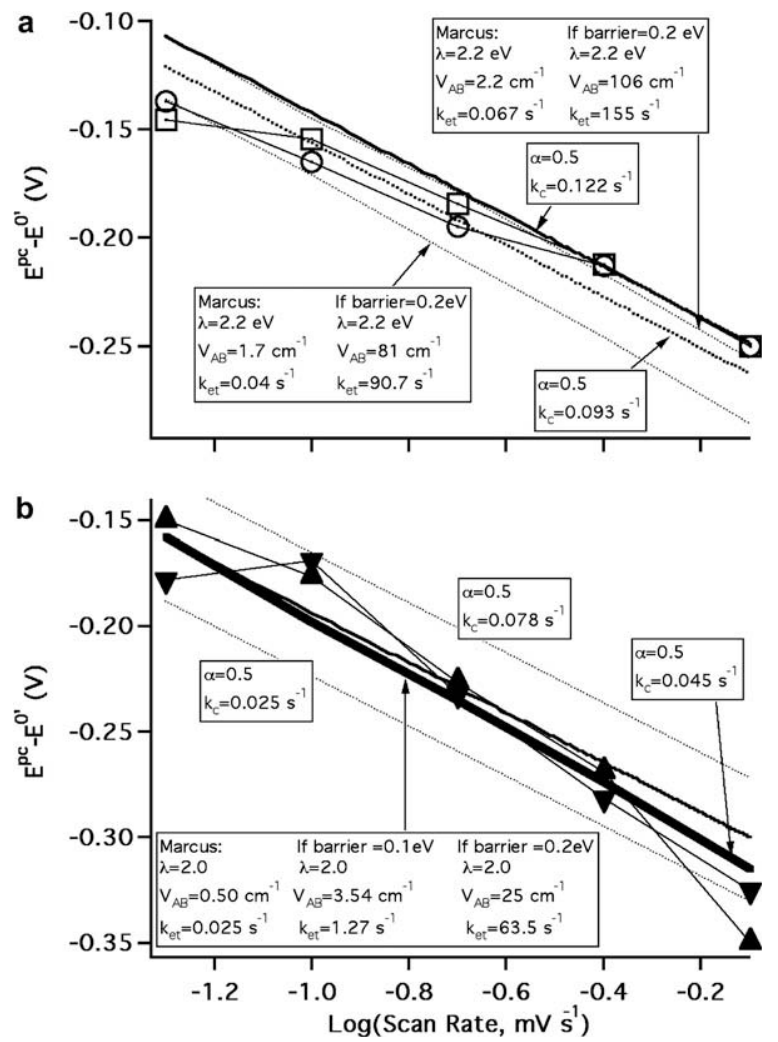

Fig. 13. (a) Overpotential of the cathodic peak $\left(\eta^{\mathrm{c}}\right)$ as a function of $\log (v)$ for the control data (open circles) and for $\Delta m t r C-\Delta o m c A$ double deletion mutant (open squares). The thick solid (intended to describe the data at high scan rate) and thick dotted (intended to fit both datasets) lines are labeled with kinetic parameters from Butler-Volmer theory. The thin dotted lines are labeled with kinetic parameters from Marcus theory (see text). (b) Overpotential of the cathodic peak $\left(\eta^{\mathrm{c}}\right)$ as a function of $\log (v)$ for the OmcA (upward pointing triangles) and MtrC (downward pointing triangles) films. The thick solid and thin dotted lines are labeled with kinetic parameters from Butler-Volmer theory assuming $\alpha=0.5$. The thick gray line is labeled with kinetic parameters from Marcus theory.

er scan rates are fully past the transition from 0 to full slope with increasing scan rate, the rate constant is $0.122 \mathrm{~s}^{-1}$. These constitute "ballpark" rate constants that can be compared to results from proteins and bacteria. The results for $\Delta m t r C-\Delta o m c A$ are nearly identical to those for the controls. Results for OmcA and MtrC films are shown in Fig. 13b. With $\alpha=0.5$, a $k_{c}$ value of $0.045 \mathrm{~s}^{-1}$ fits both the OmcA and MtrC data reasonably well. To convey uncertainty, we have plotted lines for $\alpha=0.5$, $k_{c}=0.025 \mathrm{~s}^{-1}$ (lower bound) and $\alpha=0.5, k_{c}=0.078 \mathrm{~s}^{-1}$ (upper bound).

For whole-cell suspensions the $\eta^{\mathrm{c}}$ vs. $\log (v)$ data are nonlinear (data not shown), probably because the assumption of diffusionless electron transfer to an adsorbed layer (inherent to the use of the Eq. (1)) does not apply in the case of organism suspensions.

For semiconducting electrodes it is possible that $\alpha \neq 0.5$. We attempted to achieve better fits to the data by using various values of $\alpha$, but the cathodic data in Fig. 13 was never accompanied by a corresponding change in slope of the 
anodic data with scan rate as required by theory. We conclude that while BV theory provides a useful first approximation of rate constants, there are aspects of the system for which it is unsuited. These include the semiconducting electrode and the redox irreversibility of the proteins and organisms (including both thermodynamic irreversibility as well as conformational "gating" in which the protein changes conformation and redox properties as a result of the initial electron transfer; e.g., see Armstrong et al. (2000).

\subsection{Kinetic analysis: Marcus approach}

Previous Marcus-based kinetic analyses of protein/electrode electron transfer have focused on metal electrodes (Tender et al., 1994; Weber and Creager, 1994) rather than semiconductors. We therefore formulate an approach for a semiconductor electrode based on Memming (1987) and Gerischer (1991). If the density of states in the valence and conduction bands does not change greatly with energy except at the band edges, and the cathodic current from the valence band is negligible at the potentials we use, the cathodic current can be approximated by

$j_{\text {cath }}^{\eta}=F k_{\text {et }} \Gamma_{o x}^{\eta} \exp \left(\frac{-e U_{S C}^{0}}{k T}\right) \exp \left(\frac{e \eta}{k T}\right)$

where $j_{\text {cath }}^{\eta}$ is the cathodic current density $\left(\mathrm{A} \mathrm{cm}^{-2}\right)$ as a function of overpotential $\eta, U_{S C}^{0}$ is the band bending (difference between surface and bulk potentials), $F$ is Faraday's constant, and $\Gamma_{o x}^{\eta}$ is the density of adsorbed oxidized protein $\left(\right.$ mole $\left.\mathrm{cm}^{-2}\right)$ constrained by $\Gamma_{r e d}^{\eta}+\Gamma_{o x}^{\eta}=\Gamma_{\text {protein }}$. For comparability with Kerisit and Rosso (2007), we use their Marcus-based expression for the nonadiabatic $k_{\text {et }}$ for the tetraheme cytochrome "Stc":

$k_{\text {et }}=\left(\frac{2 \pi}{h \sqrt{4 \pi \lambda k T}}\right)\left|V_{\mathrm{AB}}\right|^{2} \exp \left[-\frac{\left(\Delta G^{0}+\lambda\right)^{2}}{4 \lambda k T}\right]$

where $\lambda$ is the reorganization energy and $V_{\mathrm{AB}}$ is a measure of the degree of interaction between the donor and acceptor states. Values of $V_{\mathrm{AB}}$ and $\lambda$ have been calculated for several configurations of adsorbed Stc on hematite (Kerisit and Rosso, 2007), affording a direct comparison to our data. $\Delta G^{0}$ is a measure of the energy difference between the donor and acceptor. Kerisit and Rosso (2007) showed, using Molecular Dynamics simulations, that for Stc the number of available surface $\mathrm{Fe}$ sites on hematite varies from 1.4 at $0.87 \mathrm{~nm}$ distance to 16 at $1.245 \mathrm{~nm}$ (for a relatively favorable surface structure). This result is consistent with observations of kinetic dispersion, as discussed above, because the value of $V_{\mathrm{AB}}$ will decrease greatly with increasing donor-acceptor distance. Thus, for larger cytochromes like OmcA or MtrC, it is unlikely that all hemes are either positioned for optimal electron transfer to hematite or are in the reduced form at any given time. Although many possibilities can be imagined that could be accounted for with a numerical prefactor in Eq. (2), we assume that there is one donor-acceptor pair per adsorbed cytochrome.

For the controls we used $\lambda=2.2 \mathrm{eV}$ as calculated for electron transfer along the $c$-axis for an oxygen-terminated hematite $\left(\begin{array}{lll}0 & 0 & 1\end{array}\right)$ surface from Kerisit and Rosso (2006).
Using Eqs. (2), (3), we calculated voltammograms from which peak positions were determined and plotted in Fig. 13. The calculations were made for scan rates of $0.05,0.1,0.2,0.4$ and $0.8 \mathrm{~V} \mathrm{~s}^{-1}$ in a simple spreadsheet using a potential step size of $5 \times 10^{-4} \mathrm{~V}$. Each step results in reduction of an amount of adsorbed protein that is then subtracted from the amount of adsorbed oxidized protein available for reduction. This treatment is identical for the anodic data if $\eta^{\mathrm{a}}=\eta^{\mathrm{c}}$.

If we assume $U_{S C}^{0}=0$ (no energy barrier) for the control data (Fig. 13), the data occur roughly within a range of $V_{\mathrm{AB}}$ from 1.7 to $2.2 \mathrm{~cm}^{-1}$, and rate constants from 0.040 to $0.067 \mathrm{~s}^{-1}$. Although the rate constants are in the same range as found for BV kinetics, unrealistically low donor-acceptor state overlap is needed to match the data. If $E^{0 \prime}=-0.12 \mathrm{~V}$ for the controls and the conduction band edge lies at about $-0.5 \mathrm{~V} \pm 0.1 \mathrm{~V}$, a barrier height of 0.3 or $0.4 \mathrm{~V}$ might be reasonable. We chose a somewhat lower barrier height of $0.2 \mathrm{eV}$ to show the effects of imposing a reasonable barrier while retaining direct comparability to the results for proteins. With a barrier height of $0.2 \mathrm{eV}$, the control data are bracketed by a $V_{\mathrm{AB}}$ range from 80 to $110 \mathrm{~cm}^{-1}$ and rate constants from 90 to $155 \mathrm{~s}^{-1}$. These results indicate less donoracceptor overlap and smaller rate constants than those calculated for electron transfer through hematite (Kerisit and Rosso, 2006). If we assume that the barrier height is $0.3 \mathrm{eV}$, the resulting $V_{\mathrm{AB}}$ is between 570 and $750 \mathrm{~cm}^{-1}$, and $k_{\text {et }}$ is between $7.8 \times 10^{3}$ and $4.5 \times 10^{3} \mathrm{~s}^{-1}$. These values are comparable to those calculated for electron hopping from $\mathrm{Fe}$ site to $\mathrm{Fe}$ site near hematite surfaces (Kerisit and Rosso, 2006) but still somewhat less than parameters for bulk hematite. In the absence of specific structural information regarding the artifactual $\mathrm{Fe}$ whose redox activity is detected in the experiments reported here, it is impossible to assign a single set of electron transfer parameters. However, the kinetic data are entirely consistent with a layer of ironcontaining material on the hematite surface in a structure distinct from that of hematite such that values of $V_{\mathrm{AB}}$ and $k_{\text {et }}$ are less than those in bulk hematite.

For OmcA and MtrC, the results of Marcus-based calculations are included in Fig. 13b. We used a reorganization energy of $2.0 \mathrm{eV}$ for these calculations, as calculated for electron transfer between hematite and hemes in Stc by (Kerisit and Rosso, 2007). $V_{\mathrm{AB}}$ varies from $0.50 \mathrm{~cm}^{-1}$ with no barrier up to $25 \mathrm{~cm}^{-1}$ for a $0.2 \mathrm{eV}$ barrier, and $k_{\mathrm{et}}$ varies from $0.025 \mathrm{~s}^{-1}$ in the absence of a barrier to $63.5 \mathrm{~s}^{-1}$ with a $0.2 \mathrm{eV}$ barrier. By comparison, calculated values of $V_{\mathrm{AB}}$ and $k_{\text {et }}$ in Table 2 of Kerisit and Rosso (2007) for electron transfer between Stc and hematite range from 0.7 to $19.7 \mathrm{~cm}^{-1}$ for $V_{\mathrm{AB}}$ and from 0.02 to $882.6 \mathrm{~s}^{-1}$ for $k_{\mathrm{et}}$. The rate constant for MtrC films exchanging electrons with conducting electrodes is in the neighborhood of $100 \mathrm{~s}^{-1}$ (Hartshorne et al., 2007). Our experimentally derived values are thus directly comparable to both calculated parameters and experimental measurements from other studies.

\subsection{Other observations}

The $E^{0 \prime}$ for OmcA is more negative than the $\operatorname{MtrC} E^{0 \prime}$. $E^{0 \prime}$ for similar deca-heme proteins are somewhat more 
negative than our values. OmcA from Shewanella frigidimarina NCIMB400 displayed two groups of hemes with redox potentials of $-243 \mathrm{mV}$ and $-324 \mathrm{mV}$ vs. SHE (Field et al., 2000). MtrA, a periplasmic deca-heme cytochrome from MR-1, was found to have multiple $E^{0 \prime}$ s, with 3 hemes having $E^{0 \prime}=-375 \mathrm{mV}$ vs. SHE and 7 hemes with $E^{0 \prime}=-200 \mathrm{mV}$ vs. SHE (Pitts et al., 2003). After adjustment to the $\mathrm{Ag} / \mathrm{AgCl}$ reference scale (add $-197 \mathrm{mV}$ ), they are much more negative than our potentials for OmcA and MtrC from $S$. oneidensis MR-1. On the other hand Hartshorne et al. (2007), as discussed above, found an $\mathrm{MtrC} E^{0 \prime}$ within the same range as found in our study.

Among the possible reasons for the above discrepancies is simply that cytochromes from $S$. frigidimarina may be different from those of MR-1. We also have no way of quantitatively considering the possible role of conformation change in the redox properties of OmcA and MtrC (though this phenomenon is well known in other cytochromes). It is entirely possible that OmcA and MtrC undergo conformation changes that alter their redox properties as part of a catalytic cycle and thus that the properties measured in one study under one set of conditions may differ from those of another study under different conditions. We have also not quantified the effect of the proteins or of the organisms on the surface properties of hematite. The size of the barrier considered in the Marcus-based calculations depends on the surface properties of the hematite. If the adsorption of proteins and organisms affects the surface charge, for example, $E_{\mathrm{FB}}$ of hematite (and the barrier to electron transfer) will change as well.

Finally, there is another possible interpretation of the agreement between our data for wild-type MR-1 cell suspensions and data the of Kim et al. (2002) and Cho and Ellington (2007). If the cell walls of the bacterial populations tested in all of these studies contain significant amounts of non-heme "adsorbed" or "cell bound" $\mathrm{Fe}$ (e.g., see Wightman and Fein, 2005) that can be reductively dissolved under anoxic conditions, then the redox behavior seen in all of the previous experiments, as well as ours, may simply reflect Fe dissolved from the cell wall and not the redox activity of enzymes like OmcA and MtrC. If this were the case in the present study, we might expect that all organisms, whether deletion mutants or not, might show the same electrochemical behavior. This is not the case. The fact that the redox behavior of the double-deletion mutant $\Delta m t r C-\Delta o m c A$ is similar controls with no proteins or organisms, whereas the presence of either protein films or cells able to make OmcA or MtrC results in distinctly different redox behavior (with a more negative $E^{0 \prime}$ ), suggests that the results can be attributed to the redox activity of OmcA and MtrC. Nevertheless, the role of non-heme Fe sorbed to cell walls requires further study.

\section{CONCLUSIONS}

This study sought to better understand electron exchange between an iron oxide electrode and the cytochromes OmcA and MtrC, as well as both wild-type and mutant MR-1 cells. Our control experiments indicate that electrode dissolution at potentials less than $E_{\mathrm{FB}}$ of hematite creates an artifactual, redox-active population of $\mathrm{Fe}$ species in the system. Nevertheless, CV of OmcA and MtrC protein films indicate that both cathodic and anodic currents are different in the presence of proteins than in their absence. This is also true of wild-type $S$. oneidensis MR-1, $\Delta o m c A$, and $\Delta m t r C$. The double deletion mutant $\Delta m \operatorname{tr} C-\Delta o m c A$ did not exchange electrons with the hematite electrode any differently from the inorganic and abiotic controls. OmcA and MtrC are thus apparently the only outer membrane metal reduction enzymes utilized by MR-1 under the tested experimental conditions. Anodic currents are consistent with the idea that functional protein complexes are more effective at electron transfer to hematite than individual proteins.

A summary of $E^{0 \prime}, E^{\mathrm{pc}}$ and $E^{\mathrm{pa}}$ for proteins and organisms is given in Table 2. $E^{0 /}(\mathrm{OmcA})$ is $-201 \mathrm{mV}$ vs. $\mathrm{Ag} /$ $\mathrm{AgCl}$, and is more negative than the $E^{0 \prime}(\mathrm{MtrC})$ of $-163 \mathrm{mV}$ vs. $\mathrm{Ag} / \mathrm{AgCl}$. The electrochemical behavior of whole-cell suspensions of wild-type MR-1 is consistent with other studies of the same organism. The electrochemistry of $\Delta o m c A$ and $\triangle m t r C$ are consistent with the $\mathrm{CV}$ of the respective proteins (MtrC for $\Delta o m c A$, and OmcA for $\Delta m t r C$ ). Butler-Volmer theory for electrode kinetics cannot fully describe our data, but with reasonable assumptions regarding Marcus electron transfer theory the $V_{\mathrm{AB}}$ and $k_{\mathrm{et}}$ values needed to describe our data are similar to those calculated or measured by others using non-hematite electrodes. Overall, OmcA and MtrC appear to be the only enzymes that directly affect electron transfer to and from hematite. There are other proteins whose absence can interrupt the electron transfer chain supplying electrons to MtrC and OmcA, but the absence of MtrC and OmcA results in voltammetry that is almost identical to controls.

\section{ACKNOWLEDGMENTS}

The authors gratefully acknowledge support from the National Science Foundation (EAR-0434019), the US Department of Energy (DE-FG02-06ER15823), and a Pacific Northwest National Laboratory Biogeochemistry Grand Challenge for this work. The content of this paper represents the views of the authors and does not represent the views of the above named organizations.

\section{REFERENCES}

Anderman M. and Kennedy J. H. (1988) Iron oxide $\left(\mathrm{Fe}_{2} \mathrm{O}_{3}\right)$. In Semiconductor Electrodes (ed. H. O. Finklea). Elsevier, Amsterdam.

Armstrong F. A., Camba R., Heering H. A., Hirst J., Jeuken L. J. C., Jones A. K., Leger C. and McEvoy J. P. (2000) Fast voltammetric studies of the kinetics and energetics of coupled electron-transfer reactions in proteins. Farad. Discuss. 116, 191203.

Armstrong F. A., Heering H. A. and Hirst J. (1997) Reactions of complex metalloproteins studied by protein-film voltammetry. Chem. Soc. Rev. 26, 167-179.

Arnold R. G., DiChristina T. J. and Hoffman M. R. (1988) Reductive dissolution of $\mathrm{Fe}(\mathrm{III})$ oxides by Pseudomonas sp. 200. Biotechnol. Bioeng. 32, 1081-1096.

Beliaev A. S., Klingeman D. M., Klappenbach J. A., Wu L., Romine M. F., Tiedje J. M., Nealson K. H., Fredrickson J. K. 
and Zhou J. (2005) Global transcriptome analysis of Shewanella oneidensis MR-1 exposed to different terminal electron acceptors. J. Bacteriol. 187, 7138-7145.

Beliaev A. S. and Saffarini D. A. (1998) Shewanella putrefaciens $m \operatorname{tr} B$ encodes an outer membrane protein required for $\mathrm{Fe}(\mathrm{III})$ and $\mathrm{Mn}(\mathrm{IV})$ reduction. J. Bacteriol. 180, 6292-6297.

Beliaev A. S., Saffarini D. A., McLaughlin J. L. and Hunnicutt D. (2001) MtrC, an outer membrane decahaem $c$ cytochrome required for metal reduction in Shewanella putrefaciens MR-1. Mol. Microbiol. 39, 722-730.

Boschloo G. and Fitzmaurice D. (1999) Spectroelectrochemistry of highly doped nanostructured tin dioxide electrodes. J. Phys. Chem. B 103, 3093-3098.

Bretschger O., Obraztsova A., Sturm C. A., Chang I. S., Gorby Y. A., Reed S. B., Culley D. E., Reardon C. L., Barua S., Romine M. F., Zhou J., Beliaev A. S., Bouhenni R., Saffarini D., Mansfeld F., Kim B.-H., Fredrickson J. K. and Nealson K. H. (2007) Current production and metal oxide reduction by Shewanella oneidensis MR-1 wild type and mutants. Appl. Environ. Microbiol. 73, 7003-7012.

Carpentier W., De Smet L., Van Beeumen J. and Brige A. (2005) Respiration and growth of Shewanella oneidensis MR-1 using vanadate as the sole electron acceptor. J. Bacteriol. 187, 32933301.

Cho E. J. and Ellington A. D. (2007) Optimization of the biological component of a bioelectrochemical cell. Bioelectrochemistry 70, 165-172.

Croal L. R., Gralnick J. A., Malasarn D. and Newman D. K. (2004) The genetics of geochemistry. Ann. Rev. Genet. 38, 175-202.

Das A. and Caccavo, Jr., F. (2000) Dissimilatory Fe(III) oxide reduction by Shewanella alga $\mathrm{BrY}$ requires adhesion. Curr. Microbiol. 40, 344-347.

DiChristina T. J., Frederickson J. K. and Zachara J. M. (2005) Enzymology of electron transport: energy generation with geochemical consequences. Rev. Mineral. Geochem. 59, 27-52.

Drever J. I. (1997) The Geochemistry of Natural Waters. PrenticeHall, New Jersey.

Eggleston C. M., Stack A. G., Rosso K. M., Higgins S. R., Bice A. M., Boese S. W., Pribyl R. D. and Nichols J. J. (2003) The structure of hematite $\left(\mathrm{a}-\mathrm{Fe}_{2} \mathrm{O}_{3}\right)\left(\begin{array}{lll}0 & 0 & 1\end{array}\right)$ surfaces in aqueous media: scanning tunneling microscopy and resonant tunneling calculations of coexisting $\mathrm{O}$ and $\mathrm{Fe}$ terminations. Geochim. Cosmochim. Acta 67, 985-1000.

Eggleston C. M., Vörös J., Shi L., Lower B. H., Droubay T. C. and Colberg P. J. S. (2008) Binding and direct electrochemistry of OmcA, an outer-membrane cytochrome from an iron reducing bacterium, with oxide electrodes: a candidate biofuel cell system. Inorg. Chim. Acta 361, 769-777.

Field S. J., Dobbin P. S., Cheesman M. R., Watmough N. J., Thomson A. J. and Richardson D. J. (2000) Purification and magneto-optical spectroscopic characterization of cytoplasmic membrane and outer membrane multiheme $c$-type cytochromes from Shewanella frigidimarina NCIMB400. J. Biol. Chem. 275, $8515-8522$.

Finklea H. O. (1988) Semiconductor electrode concepts and terminology. In Semiconductor Electrodes (ed. H. O. Finklea). Elsevier, Amsterdam.

Fredrickson J. K. and Gorby Y. A. (1996) Environmental processes mediated by iron-reducing bacteria. Curr. Opin. Biotechnol. 7, 287-294.

Fredrickson J. K., Romine M. F., Beliaev A. S., Auchtung J. M., Driscoll M. E., Gardner T. S., Nealson K. H., Osterman A. L., Pinchuk G., Reed J. L., Rodionov D. A., Rodrigues J. L. M., Saffarini D. A., Serres M. H., Spormann A. M., Zhulin I. B. and Tiedje J. M. (2008) Towards environmental systems biology of Shewanella. Nat. Rev. Microbiol. 6, 592-603.
Gerischer H. (1991) Electron-transfer kinetics of redox reactions at the semiconductor/electrolyte contact. A new approach. $J$. Phys. Chem. 95, 1356-1359.

Giometti D. S. (2006) Tale of two metal reducers: comparative proteome analysis of Geobacter sulfurreducens PCA and Shewanella oneidensis MR-1. In Microbial Proteomics: Fundamental Biology of Whole Organisms (eds. I. Humphrey-Smith and M. Hecker). John Wiley \& Sons.

Gorby Y. A., Yanina S., McLean J. S., Rosso K. M., Moyles D., Dohnalkova A., Beveridge T. J., Chang I. S., Kim B. H., Kim K. S., Culley D. E., Reed S. B., Romine M. F., Saffarini D. A., Hill E. A., Shi L., Elias D. A., Kennedy D. W., Pinchuk G., Watanabe K., Ishii S., Logan B., Nealson K. H. and Fredrickson J. K. (2006) Electrically conductive bacterial nanowires produced by Shewanella oneidensis strain MR-1 and other microorganisms. Proc. Natl. Acad. Sci. USA 103, 11358-11363.

Grätzel M. (1989) Heterogeneous Photochemical Electron Transfer. CRC Press, Inc., Boca Raton, Florida.

Hartshorne R. S., Jepson B. N., Clarke T. A., Field S. J., Fredrickson J., Zachara J., Shi L., Butt J. N. and Richardson D. J. (2007) Characterization of Shewanella oneidensis MtrC: a cell-surface decaheme cytochrome involved in respiratory electron transport to extracellular electron acceptors. J. Biol. Inorg. Chem. 12, 1083-1094.

Heidelberg J. F., Paulsen I. T., Nelson K. E., Gaidos E. J., Nelson W. C., Read T. D., Eisen J. A., Seshadri R., Ward N., Methe B., Clayton R. A., Meyer T., Tsapin A., Scott J., Beanan M., Brinkac L., Daugherty S., Deboy R. T., Dodson R. J., Durkin A. S., Haft D. H., Kolonay J. F., Madupu R., Peterson J. D., Umayam L. A., White O., Wolf A. M., Vamathevan J., Weidman J., Impraim M., Lee K., Berry K., Lee C., Mueller J., Khouri H., Gill J., Utterback T. R., Mcdonald L. A., Feldblyum T. V., Smith H. O., Venter J. C., Nealson K. H. and Fraser C. M. (2002) Genome sequence of the dissimilatory metal ion-reducing bacterium Shewanella oneidensis. Nat. Biotechnol. 20, 1118-1123.

Hernandez M. E., Kappler A. and Newman D. K. (2004) Phenazines and other redox-active antibiotics promote microbial mineral reduction. Appl. Environ. Microbiol. 70, 921-928.

Hernandez M. E. and Newman D. K. (2001) Extracellular electron transfer. Cell. Mol. Life Sci. 58, 1562-1571.

Hirst J. and Armstrong F. A. (1998) Fast-scan cyclic voltammetry of protein films on pyrolytic graphite edge electrodes: characteristics of electron exchange. Anal. Chem. 70, 5062-5071.

Honeychurch M. J. and Rechnitz G. A. (1998) Voltammetry of adsorbed molecules. Part 2: irreversible redox systems. Electroanalysis 10, 453-457.

Horowitz G. (1983) Capacitance-voltage measurements and flatband potential determination on $\mathrm{Zr}$-doped $\alpha-\mathrm{Fe}_{2} \mathrm{O}_{3}$ singlecrystal electrodes. J. Electroanal. Chem. 159, 421-436.

Kappler A., Benz M., Schink B. and Brune A. (2004) Electron shuttling via humic acids in microbial iron(III) reduction in a freshwater sediment. FEMS Microbiol. Ecol. 47, 85-92.

Kerisit S. and Rosso K. M. (2006) Computer simulation of electron transfer at hematite surfaces. Geochim. Cosmochim. Acta $\mathbf{7 0}$, 1888-1903.

Kerisit S. and Rosso K. M. (2007) Molecular computational investigation of electron transfer kinetics across cytochromeiron oxide interfaces. J. Phys. Chem. C 111, 11363-11375.

Khare N., Eggleston C. M. and Lovelace D. M. (2005) Sorption and direct electrochemistry of mitochondrial cytochrome $c$ on hematite surfaces. Clays Clay Min. 53, 564-571.

Khare N., Eggleston C. M., Lovelace D. M. and Boese S. W. (2006a) Structural and redox properties of mitochondrial cytochrome $c$ co-sorbed with phosphate on hematite $\left(\alpha-\mathrm{Fe}_{2} \mathrm{O}_{3}\right)$ surfaces. J. Colloid Interface Sci. 303, 404-414. 
Khare N., Lovelace D. M., Eggleston C. M., Swenson M. and Magnuson T. S. (2006b) Redox-linked conformation change and electron transfer between monoheme $c$-type cytochromes and oxides. Geochim. Cosmochim. Acta 70, 4332-4342.

Kim B. H., Ikeda T., Park H. S., Kim H. J., Hyun M. S., Kano K., Takagi K. and Tatsumi H. (1999a) Electrochemical activity of an Fe(III)-reducing bacterium, Shewanella putrefaciens IR-1, in the presence of alternative electron acceptors. Biotechnol. Tech. 13, 475-478.

Kim B. H., Kim H. J., Hyun M. S. and Park D. H. (1999b) Direct electrode reaction of $\mathrm{Fe}(\mathrm{III})$-reducing bacterium, Shewanella putrefaciens. J. Microbiol. Biotechnol. 9, 127-131.

Kim H. J., Park H. S., Hyun M. S., Chang I. S., Kim M. and Kim B. H. (2002) A mediator-less microbial fuel cell using a metal reducing bacterium, Shewanella putrefaciens. Enzyme Microb. Technol. 30, 145-152.

Kolker E., Picone A. F., Galperin M. Y., Romine M. F., Higdon R., Makarova K. S., Kolker N., Anderson G. A., Qiu X., Auberry K. J., Babnigg G., Beliaev A. S., Edlefsen P., Elias D. A., Gorby Y. A., Holzman T., Klappenbach J. A., Konstantinidis K. T., Land M. L., Lipton M. S., McCue L.-A., Monroe M., Pasa-Tolic L., Pinchuk G., Purvine S., Serres M. H., Tsapin S., Zakrajsek B. A., Zhu W., Zhou J., Larimer F. W., Lawrence C. E., Riley M., Collart F. R., Yates, III, J. R., Smith R. D., Giometti C. S., Nealson K. H., Fredrickson J. K. and Tiedje J. M. (2005) Global profiling of Shewanella oneidensis MR-1: expression of hypothetical genes and improved functional annotations. Proc. Natl. Acad. Sci. USA 102, 2099-2104.

Kostka J. and Nealson K. H. (1998) Isolation, cultivation and characterization of iron- and manganese-reducing bacteria. In Techniques in Microbial Ecology (eds. R. S. Burlage, R. Atlas, D. Stahl, G. Geesey and G. Sayler). Oxford University Press, US.

Laviron E. (1979) General expression of the linear potential sweep voltammogram in the case of diffusionless electrochemical systems. J. Electroanalyt. Chem. 101, 19-28.

Leland J. K. and Bard A. J. (1987) Photochemistry of colloidal semiconducting iron oxide polymorphs. J. Phys. Chem. 91, 5076-5083.

Lies D. P., Hernandez M. E., Kappler A., Mielke R. E., Gralnick J. A. and Newman D. K. (2005) Shewanella oneidensis MR-1 uses overlapping pathways for iron reduction at a distance and by direct contact under conditions relevant for biofilms. Appl. Environ. Microbiol. 71, 4414-4426.

Lloyd J. R. (2003) Microbial reduction of metals and radionuclides. FEMS Microbiol. Rev. 27, 411-425.

Lovley D. (1995) Bioremediation of organic and metal contaminants with dissimilatory metal reduction. J. Ind. Microbiol. 14, 85-93.

Lovley D. R. (1991) Dissimilatory Fe(III) and Mn(IV) reduction. Microbiol. Rev. 55, 259-287.

Lovley D. R. (1993) Dissimilatory metal reduction. Ann. Rev. Microbiol. 47, 263-290.

Lovley D. R. (1997) Microbial Fe(III) reduction in subsurface environments. FEMS Microbiol. Rev. 20, 305-313.

Lovley D. R., Baedecker M. J., Lonergan D. J., Cozzarelli I. M., Phillips E. J. P. and Siegal D. I. (1989) Oxidation of aromatic contaminants coupled to microbial iron reduction. Nature 339 , 297-299.

Lovley D. R., Coates J. D., Blunt-Harris E. L., Phillips E. J. P. and Woodward J. C. (1996) Humic substances as electron acceptors for microbial respiration. Nature 382, 445-448.

Lovley D. R., Phillips E. F. and Lonergan D. J. (1991) Enzymatic versus non-enzymatic mechanisms for $\mathrm{Fe}(\mathrm{III})$ reduction in aquatic sediments. Environ. Sci. Technol. 25, 1062-1067.
Lovley D. R. and Phillips E. J. P. (1988) Novel mode of microbial energy metabolism: organic carbon oxidation coupled to dissimilatory reduction of iron or manganese. Appl. Environ. Microbiol. 54, 1472-1480.

Lower B. H., Shi L., Yongsunthon R., Droubay T. C., McCready D. E. and Lower S. K. (2007) Specific bonds between an iron oxide surface and outer membrane cytochromes MtrC and OmcA from Shewanella oneidensis MR-1. J. Bacteriol. 189, 4944-4952.

Lower B. H., Yongsunthon R., Shi L., Wilding L., Gruber H. J., Wigginton N. S., Reardon C. L., Pinchuk G. E., Droubay T. C., Boily J. F. and Lower S. K. (2009) Antibody recognition force microscopy shows that outer membrane cytochrome OmcA and MtrC are expressed on the exterior surface of Shewanella oneidensis MR-1. Appl. Environ. Microbiol. 75, 2931-2935.

Luu Y. S. and Ramsay J. A. (2003) Review: microbial mechanisms of accessing insoluble $\mathrm{Fe}(\mathrm{III})$ as an energy source. World $J$. Microbiol. Biotechnol. 19, 215-225.

Magnuson T. S., Isoyama N., Hodges-Myerson A. L., Davidson G., Maroney M. J., Geesey G. G. and Lovley D. R. (2001) Isolation, characterization and gene sequence analysis of a membrane-associated $89 \mathrm{kDa} \mathrm{Fe}(\mathrm{III})$ reducing cytochrome $c$ from Geobacter sulfurreducens. Biochem. J. 359, 147-152.

Markwiese J. T. and Colberg P. J. S. (2000) Bacterial reduction of copper-contaminated ferric oxide: copper toxicity and the interaction between fermentative and iron-reducing bacteria. Arch. Environ. Contam. Toxicol. 38, 139-146.

Marshall M. J., Beliaev A. S., Dohnalkova A. C., Kennedy D. W., Shi L., Wang Z., Boyanov M. I., Lai B., Kemner K. M., McLean J. S., Reed S. B., Culley D. E., Bailey V. L., Simonson C. J., Saffarini D. A., Romine M. F., Zachara J. M. and Fredrickson J. K. (2006) $C$-type cytochrome-dependent formation of U(IV) nanoparticles by Shewanella oneidensis. PLoS Biol. 4, e268.

Marsili E., Baron D. B., Shikhare I. D., Coursolle D., Gralnick J. A. and Bond D. R. (2008) Shewanella secretes flavins that mediate extracellular electron transfer. Proc. Natl. Acad. Sci. USA 105, 3968-3973.

Memming R. (1987) Charge transfer kinetics at semiconductor electrodes. Ber. Bunsenges. Phys. Chem. 91, 353-361.

Methe B. A., Webster J., Nevin K., Eisen J. A., Paulsen I. T., Nelson W., Heidelberg J. F., Wu D., Wu M., Ward N., Beanan M. J., Dodson R. J., Madupu R., Brinkac L. M., Daugherty S. C., DeBoy R. T., Durkin A. S., Gwinn M., Kolonay J. F., Sullivan S. A., Haft D. H., Selengut J., Davidsen T. M., Zafar N., White O., Tran B., Romero C., Forberger H. A., Weidman J., Khouri H., Feldblyum T. V., Utterback T. R., Van Aken S. E., Lovley D. R. and Fraser C. M. (2003) Genome of Geobacter sulfurreducens: metal reduction in subsurface environments. Science 302, 1967-1969.

Meyer T. E., Tsapin A. I., Vandenberghe I., de Smet L., Frishman D., Nealson K. H., Cusanovich M. A. and van Beeumen J. J. (2004) Identification of 42 possible cytochrome $C$ genes in the Shewanella oneidensis genome and characterization of six soluble cytochromes. OMICS 8, 57-77.

Morrison S. R. (1980) Electrochemistry at Semiconductor and Oxidized Metal Electrodes. Plenum Press, New York.

Myers C. R. and Myers J. M. (1992) Localization of cytochromes to the outer membrane of anaerobically grown Shewanella putrefaciens MR-1. J. Bacteriol. 174, 3429-3438.

Myers C. R. and Myers J. M. (1993) Ferric reductase is associated with the membranes of anaerobically grown Shewanella putrefaciens MR-1. FEMS Microbiol. Lett. 108, 15-22.

Myers C. R. and Myers J. M. (1997) Cloning and sequence of cymA, a gene encoding a tetraheme cytochrome $c$ required for 
reduction of iron(III), fumarate, and nitrate by Shewanella putrefaciens MR-1. J. Bacteriol. 179, 1143-1152.

Myers C. R. and Myers J. M. (2002) MtrB is required for proper incorporation of the cytochromes OmcA and OmcB into the outer membrane of Shewanella putrefaciens MR-1. Appl. Environ. Microbiol. 68, 5585-5594.

Myers C. R. and Myers J. M. (2003) Cell surface exposure of the outer membrane cytochromes of Shewanella oneidensis MR-1. Lett. Appl. Microbiol. 37, 254-258.

Myers C. R. and Nealson K. H. (1988) Bacterial manganese reduction and growth with manganese oxide as the sole electron acceptor. Science 240, 1319-1321.

Myers J. M. and Myers C. R. (2001) Role for outer membrane cytochromes OmcA and mcB of Shewanella putrefaciens MR-1 in reduction of manganese dioxide. Appl. Environ. Microbiol. 67, 260-269.

Nevin K. P. and Lovley D. R. (2000) Lack of production of electron-shuttling compounds or solubilization of $\mathrm{Fe}(\mathrm{III})$ during reduction of insoluble $\mathrm{Fe}(\mathrm{III})$ oxide by Geobacter metallireducens. Appl. Environ. Microbiol. 66, 2248-2251.

Nevin K. P. and Lovley D. R. (2002) Mechanisms for accessing insoluble $\mathrm{Fe}(\mathrm{III})$ oxide during dissimilatory $\mathrm{Fe}(\mathrm{III})$ rreduction by Geothrix fermentans. Appl. Environ. Microbiol. 68, 22942299.

Newman D. K. and Kolter R. (2000) A role for excreted quinones in extracellular electron transfer. Nature 405, 94-97.

Pitts K. E., Dobbin P. S., Reyes-Ramirez F., Thomson A. J., Richardson D. J. and Seward H. E. (2003) Characterization of the Shewanella oneidensis MR-1 decaheme cytochrome MtrA. J. Biol. Chem. 278, 27758-27765.

Reguera G., McCarthy K. D., Mehta T., Nicoll J. S., Tuominen M. T. and Lovley D. R. (2005) Extracellular electron transfer via microbial nanowires. Nature 435, 1098-1101.

Reguera G., Pollina R. B., Nicoll J. S. and Lovley D. R. (2007) Possible nonconductive role of Geobacter sulfurreducens pilus nanowires in biofilm formation. J. Bacteriol. 189, 2125-2127.

Richardson D. J. (2000) Bacterial respiration: a flexible process for a changing environment. Microbiology-UK 146, 551-571.

Rooney-Varga J. N., Anderson R. T., Fraga J. L., Ringelberg D. B. and Lovley D. R. (1999) Microbial communities associated with anaerobic benzene degradation in a petroleum-contaminated aquifer. Appl. Environ. Microbiol. 65, 3056-3063.

Ross D. E., Ruebush S. S., Brantley S. L., Hartshorne R. S., Clarke T. A., Richardson D. J. and Tien M. (2007) Characterization of protein-protein interactions involved in iron reduction by Shewanella oneidensis MR-1. Appl. Environ. Microbiol. 73, 5797-5808.

Ruebush S. S., Brantley S. L. and Tien M. (2006) Reduction of soluble and insoluble iron forms by membrane fractions of Shewanella oneidensis grown under aerobic and anaerobic conditions. Appl. Environ. Microbiol. 72, 2925-2935.

Shi L., Chen B., Wang Z., Elias D. A., Mayer M. U., Gorby Y. A., Ni S., Lower B. H., Kennedy D. W., Wunschel D. S., Mottaz H. M., Marshall M. J., Hill E. A., Beliaev A. S., Zachara J. M., Fredrickson J. K. and Squier T. C. (2006) Isolation of a highaffinity functional protein complex between OmcA and MtrC: two outer membrane decaheme $c$-type cytochromes of Shewanella oneidensis MR-1. J. Bacteriol. 188, 4705-4714.
Shi L., Deng S., Marshall M. J., Wang Z., Kennedy D. W., Dohnalkova A. C., Mottaz H. M., Hill E. A., Gorby Y. A., Beliaev A. S., Richardson D. J., Zachara J. M. and Fredrickson J. K. (2008) Direct involvement of Type II secretion system in extracellular translocation of Shewanella oneidensis outer membrane cytochromes MtrC and OmcA. J. Bacteriol. 0051, 4-08.

Shi L., Squier T. C., Zachara J. M. and Fredrickson J. K. (2007) Respiration of metal (hydr)oxides by Shewanella and Geobacter: a key role for multihaem $c$-type cytochromes. Mol. Microbiol. 65, 12-20.

Taillefert M., Beckler J. S., Carey E., Burns J. L., Fennessey C. M. and DiChristina T. J. (2007) Shewanella putrefaciens produces an $\mathrm{Fe}(\mathrm{III})$-solubilizing organic ligand during anaerobic respiration on insoluble Fe(III) oxides. J. Inorg. Biochem. 101, 1760 1767.

Tender L., Carter M. T. and Murray R. W. (1994) Cyclic voltammetric analysis of ferrocene alkanethiol monolayer electrode kinetics based on Marcus theory. Anal. Chem. 66, 3173-3181.

Tiedje J. M. (2002) Shewanella - the environmentally versatile genome. Nat. Biotechnol. 20, 1093-1094.

Turick C. E., Tisa L. S. and Caccavo, Jr., F. (2002) Melanin production and use as a soluble electron shuttle for $\mathrm{Fe}(\mathrm{III})$ oxide reduction and as a terminal electron acceptor by Shewanella algae BrY. Appl. Environ. Microbiol. 68, 2436-2444.

Urrutia M. M., Roden E. E. and Zachara J. M. (1999) Influence of aqueous and solid-phase $\mathrm{Fe}(\mathrm{II})$ complexants on microbial reduction of crystalline iron(III) oxides. Environ. Sci. Technol. 33, $4022-4028$.

Venkateswaran K., Moser D. P., Dollhopf M. E., Lies D. P., Saffarini D. A., MacGregor B. J., Ringelberg D. B., White D. C., Nishijima M., Sano H., Burghardt J., Stackebrandt E. and Nealson K. H. (1999) Polyphasic taxonomy of the genus Shewanella and description of Shewanella oneidensis sp. Nov. Intl. J. Syst. Bacteriol. 49, 705-724.

Viamajala S., Peyton B. M., Apel A. and Petersen J. N. (2002) Chromate/nitrite interactions in Shewanella oneidensis MR-1: evidence for multiple hexavalent chromium $[\mathrm{Cr}(\mathrm{VI})]$ reduction mechanisms dependent on physiological growth conditions. Biotechnol. Bioeng. 78, 770-778.

von Canstein H., Ogawa J., Shimizu S. and Lloyd J. R. (2008) Secretion of flavins by Shewanella species and their role in extracellular electron transfer. Appl. Environ. Microbiol. 74, 615-623.

Weber K. and Creager S. E. (1994) Voltammetry of redox-active groups irreversibly adsorbed onto electrodes. Treatment using the Marcus relation between rate and overpotential. Anal. Chem. 66, 3164-3172.

Wightman P. G. and Fein J. B. (2005) Iron adsorption by Bacillus subtilis bacterial cell walls. Chem. Geol. 216, 177-189.

Xiong Y., Shi L., Chen B., Mayer M. U., Lower B. H., Londer Y., Bose S., Hochella M. F., Fredrickson J. K. and Squier T. C. (2006) High-affinity binding and direct electron transfer to solid metals by the Shewanella oneidensis MR-1 outer membrane $c$ type cytochrome OmcA. J. Am. Chem. Soc. 128, 13978-13979. 